\title{
الرقص الطقوسي ..الطواف لترميم مركزية الذات
}

\section{دراسة ثقافية}

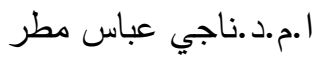

جامعة ذي قار -كلية الآداب

\section{الرقص والصلاة}

تعدّ الثعائر والطقوس لازمةً مهمةً في كلّ دينٍ، لأنّ وجودها ينبع من ديمومة العقيدة ذاتها، فهي

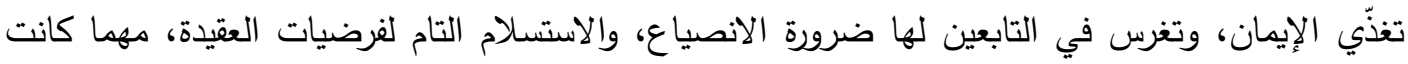

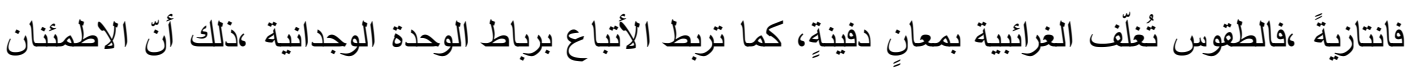

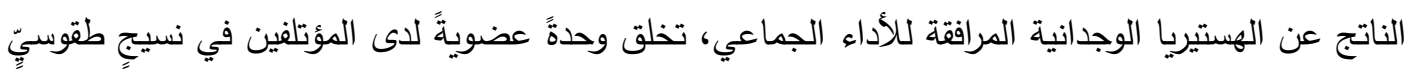

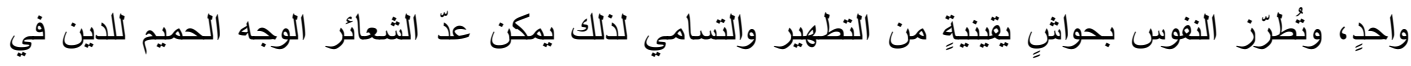

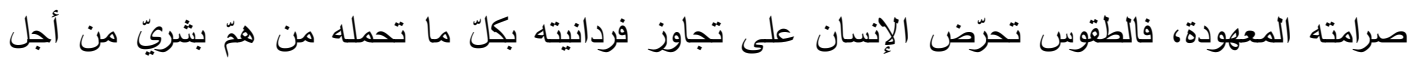

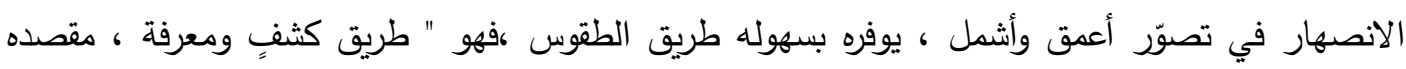
خلاص النفس والتحقق من حقيقة الذات الإلهية، رغبة في الاتصال بالئل بالمطلق، والمعرفة اليقينية بالله من خلال

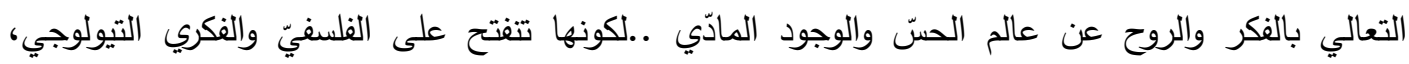

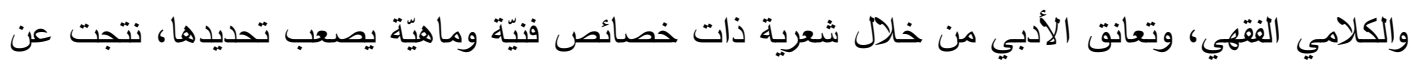

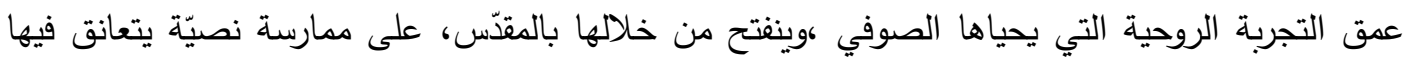

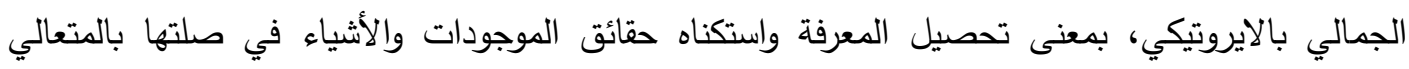

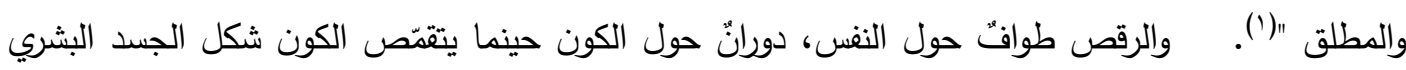

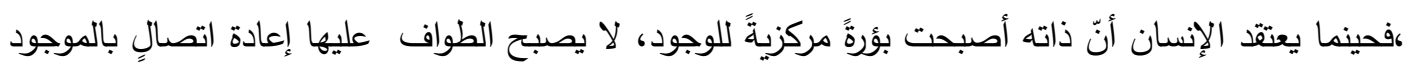

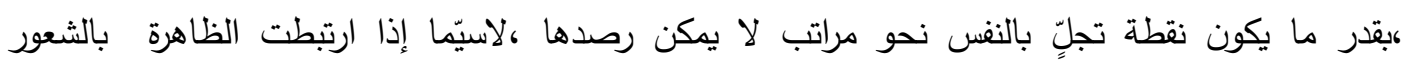

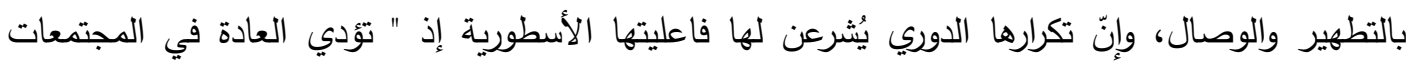

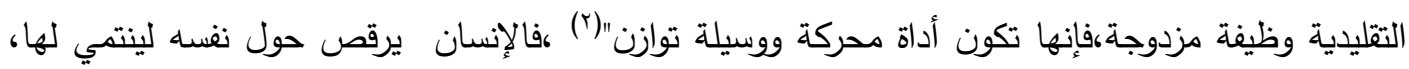

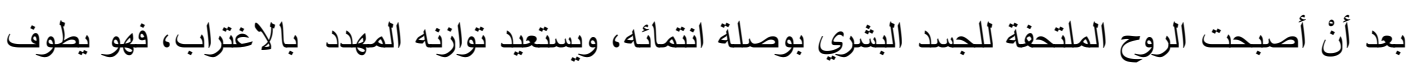


حولها ليرسخ ارتباطه بالقيم العليا التي تمترست فيها، وتزيد مناعته الروحية.. يطوف حول ذاته ليجذَّرها

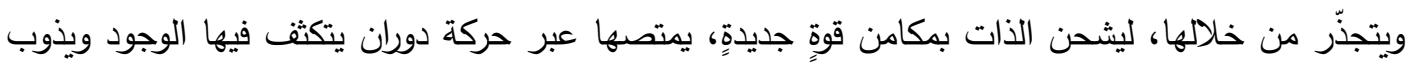

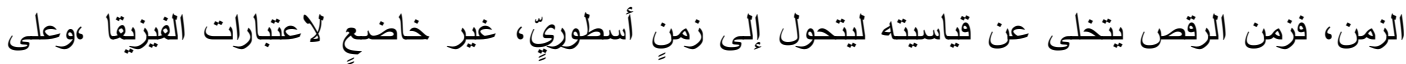

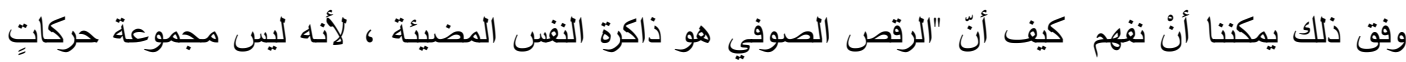

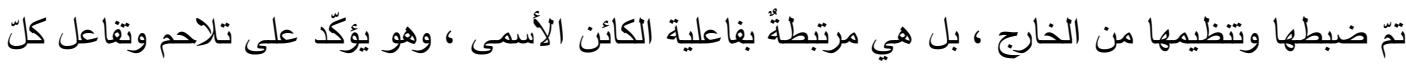

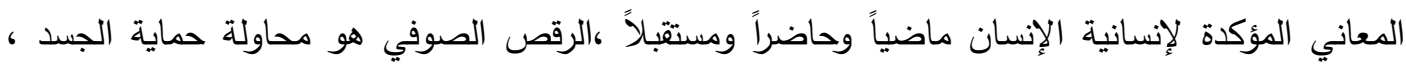

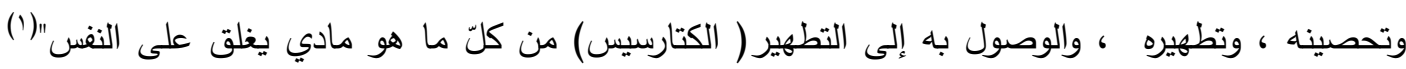

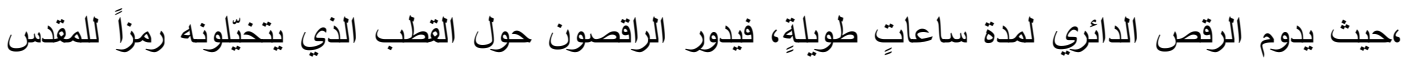

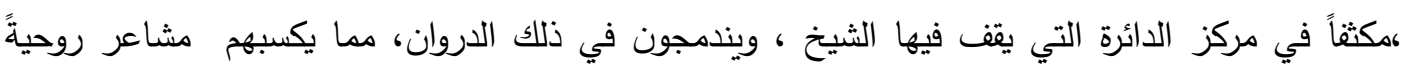

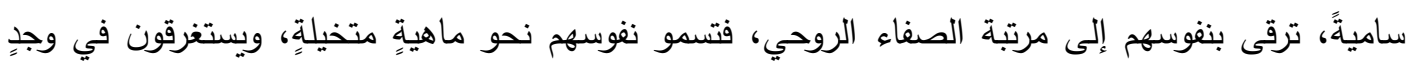

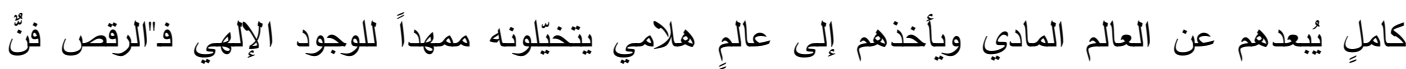

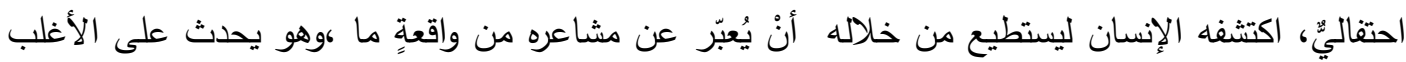

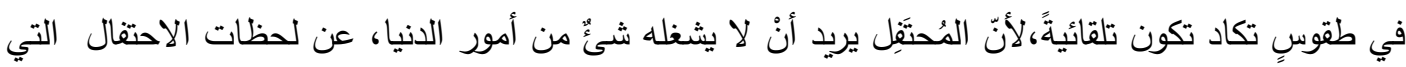

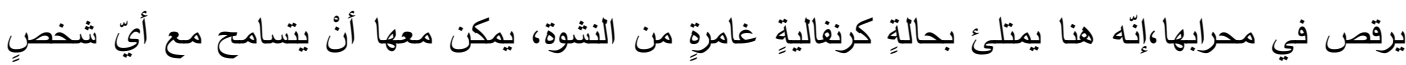

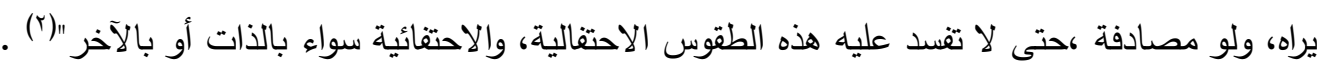

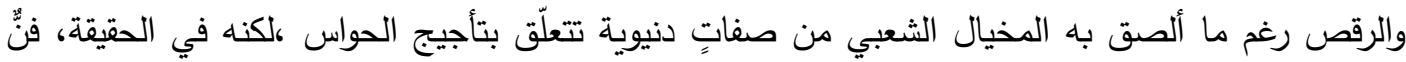

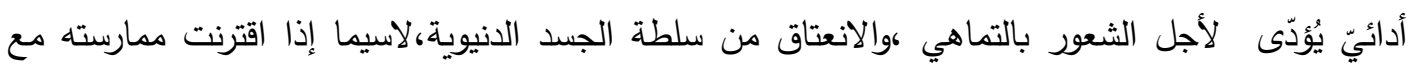

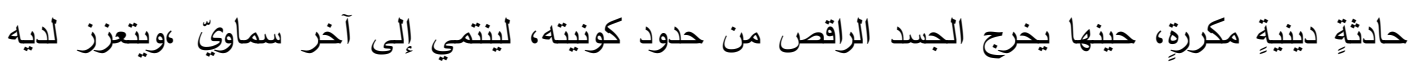

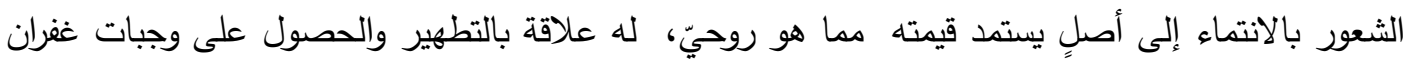

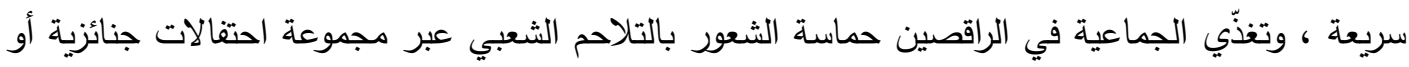

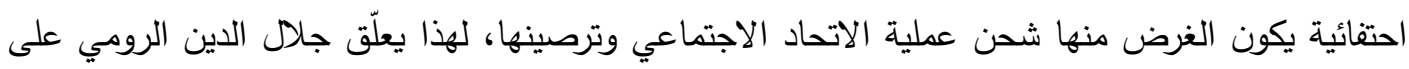

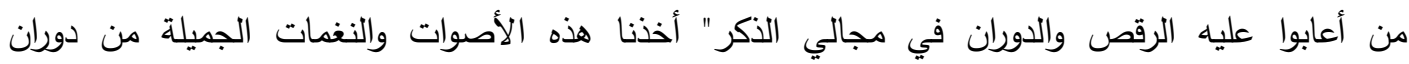

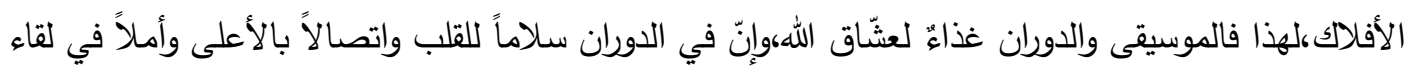

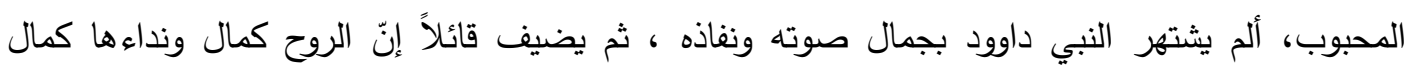

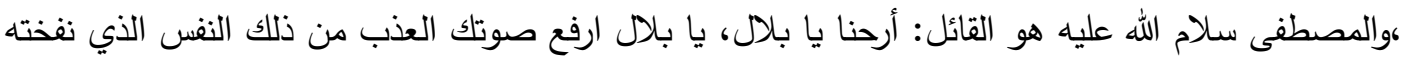

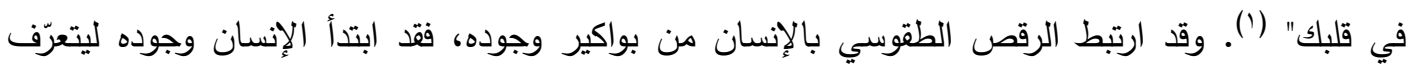

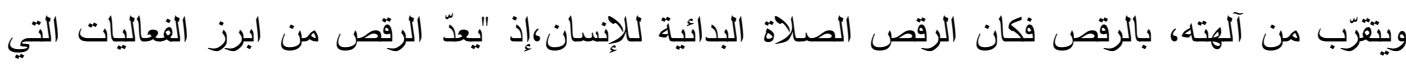




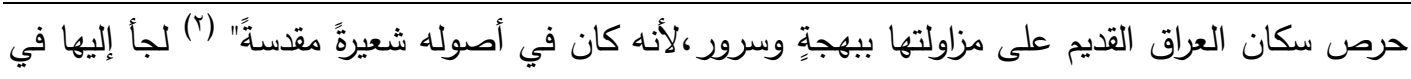

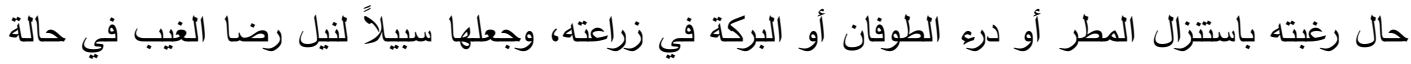

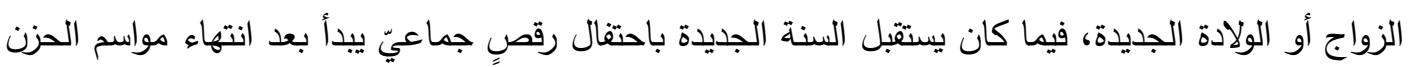

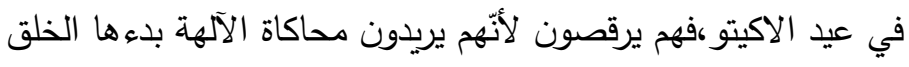
عبر ذلك الطقس الوجداني : n وفي بطن أعماقها "تعامت" التقى الآلهة يرقصون وما كان في مقدور كبير الآلهة آبسو أن يردهم عن صخبهم وعلى الرغم منها صمتت تعامت واسر ابسو إلى تابعه ممو هيا يا مُذهب الحزن نذهب معا إلى تعامت واخذ الثلاثة يتشاورون في أمر الأبناء"(()

فالرقص تبعاً لهذه الأسطورة جزءٌ حيويٌّ من الناموس الديني للرافديني القديم، وعملية تقليد الإله في جانبها

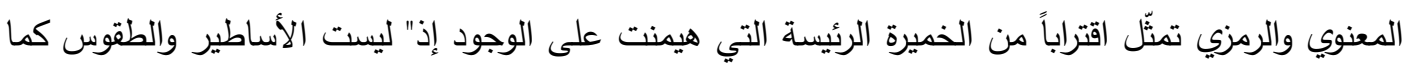

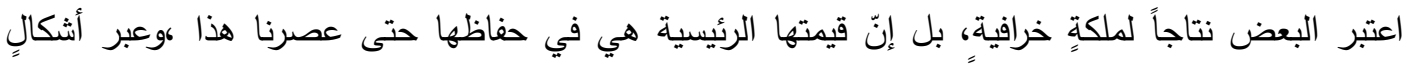

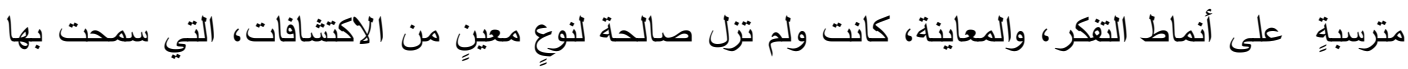

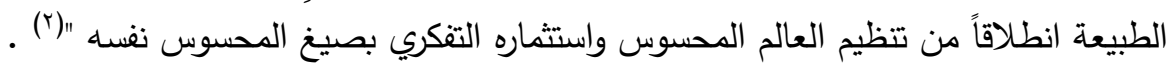

ويعدّ الرقص من أقدم الوسائل التي كان الإنسان يعبّر بها عن انفعالاته، بسبب قصور اللغة المنطوقة، أو

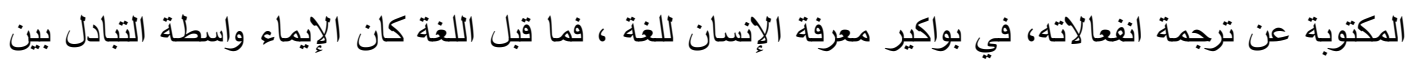

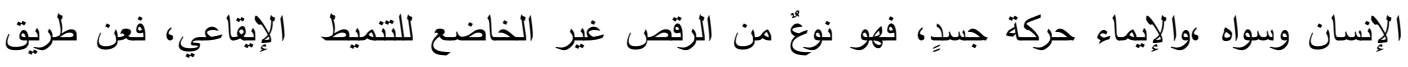

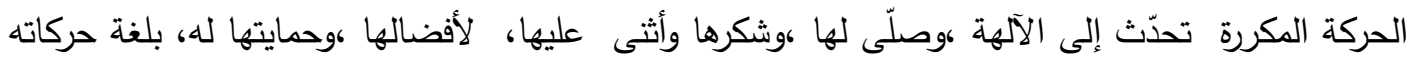

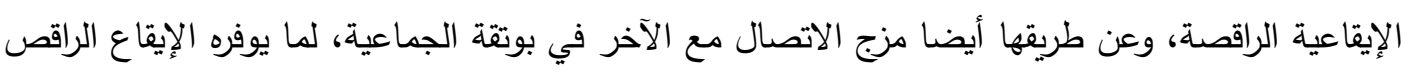

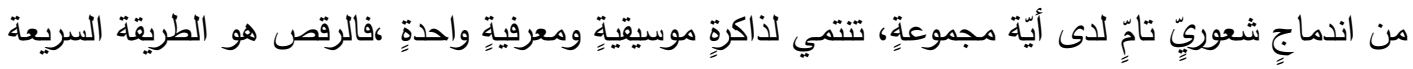
التي تذيب الهمجية وتعزّز مشاعر المحبة لدى الآخرين و تُشَّب التقديس نحو الآلهة ، وفي الرقص أيضاً 
تتكثف مشاعر الحماس، والكره نحو الأعداء في صراعاتها التنافسية ،لذلك غدا الرقص الحربي مادةً لتركيز

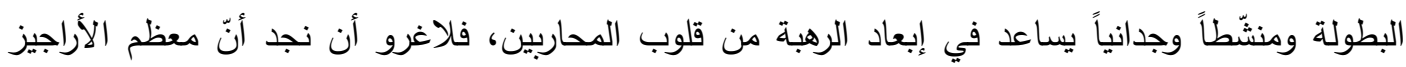

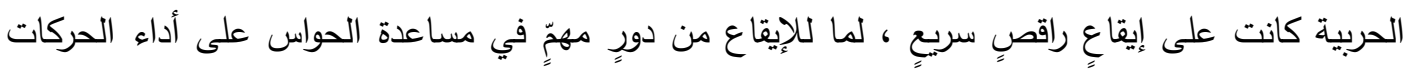

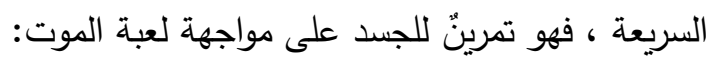

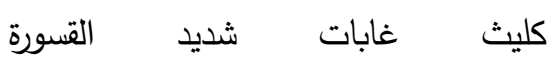

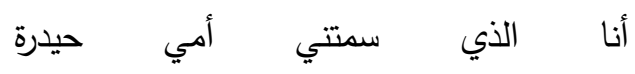
أكيلكم بالصاع كيل السندرة(广)

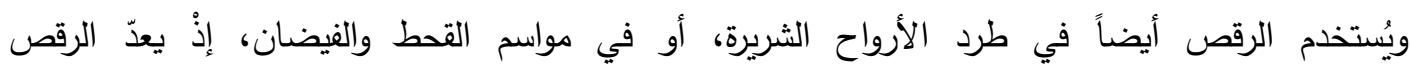

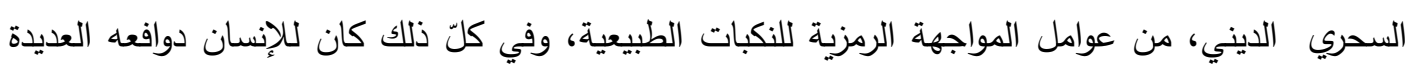

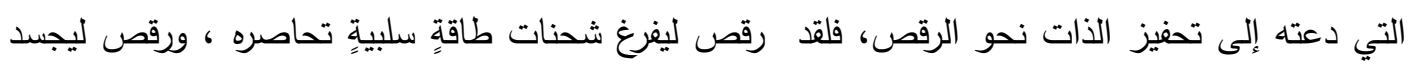
بطولةً بحاجةٍ لها لترصين وجوده ، ورقص ليحتفل بقنصٍ تجسيداً لعقيدة القربان التي تتطلب مناخاً احتفالياً

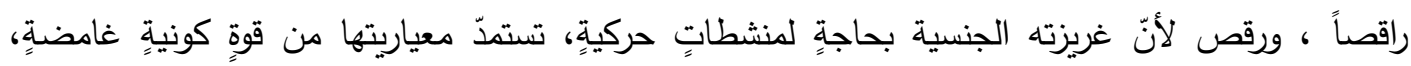

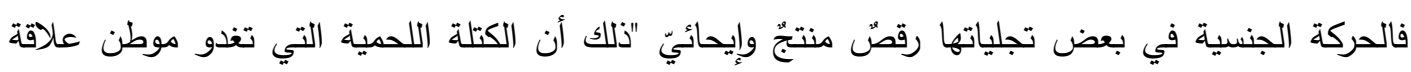

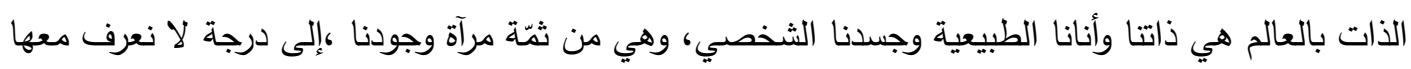

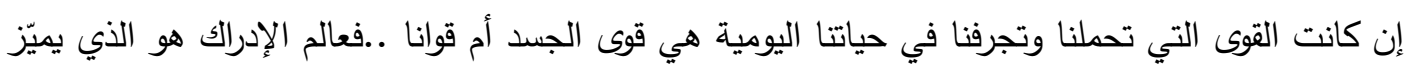

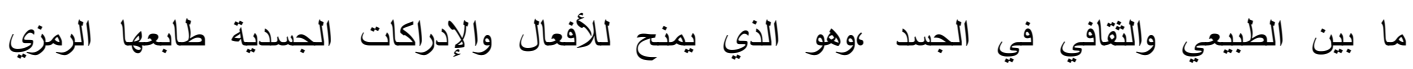

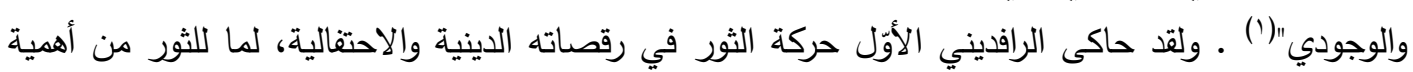

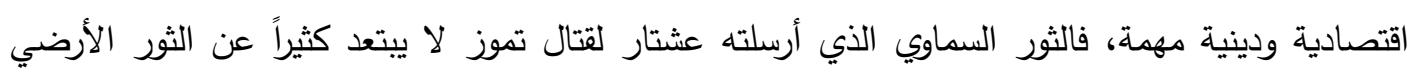

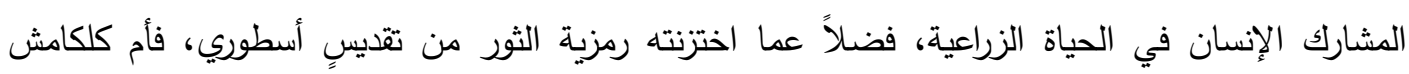

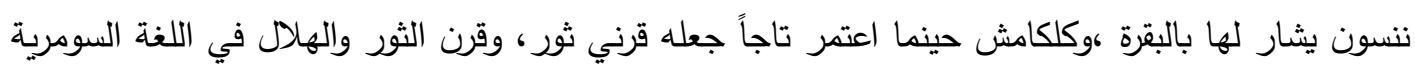

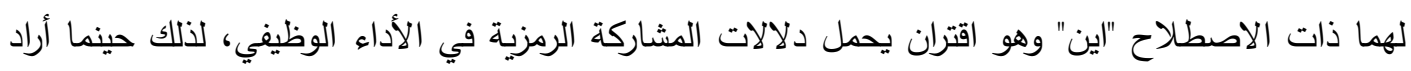

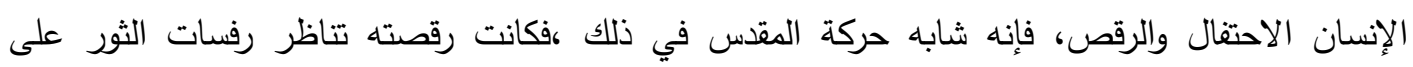

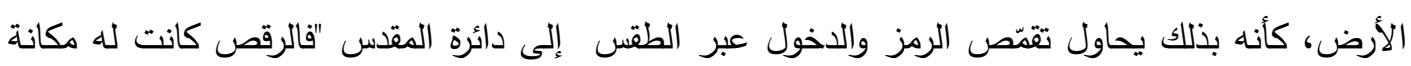

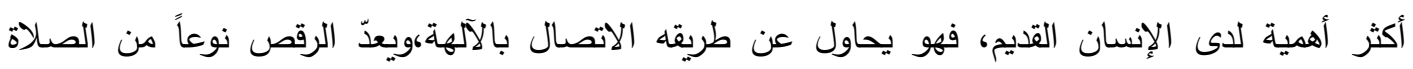

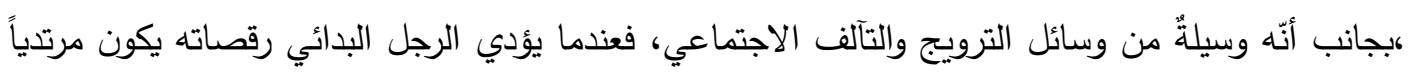

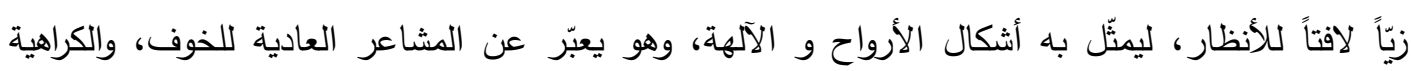

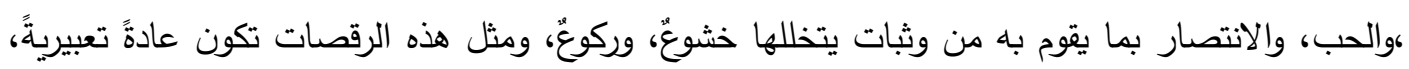


متضمنةً الحركات البدنية لتمثيل حركات عناصر البيئة الطبيعية التي يعيش فيها كوثبة الحيوان، وتحرّك

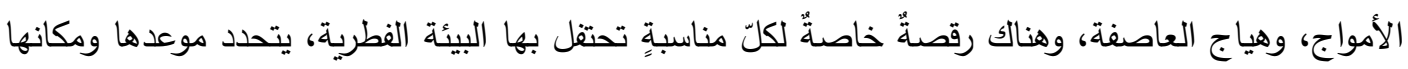

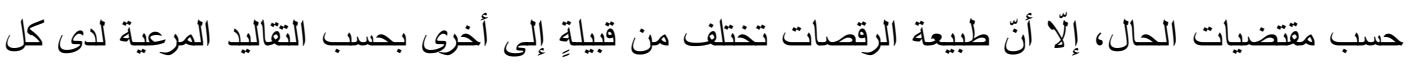

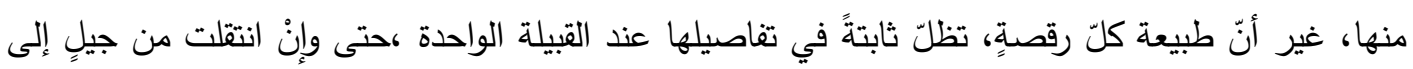

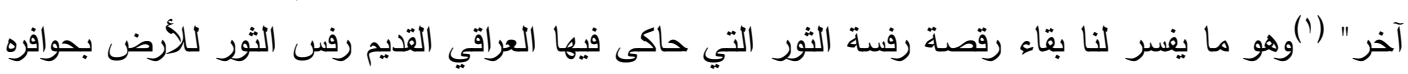

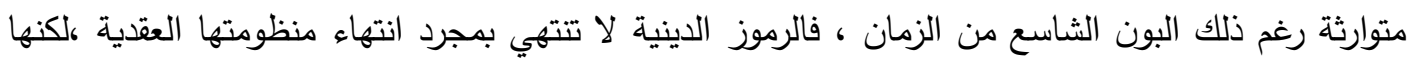

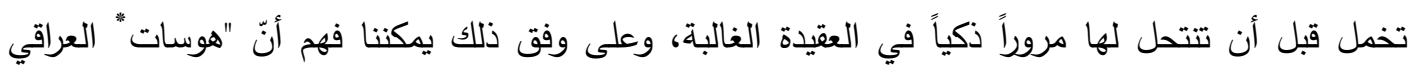

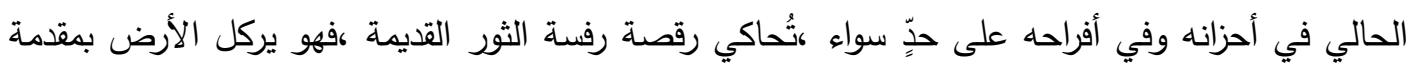

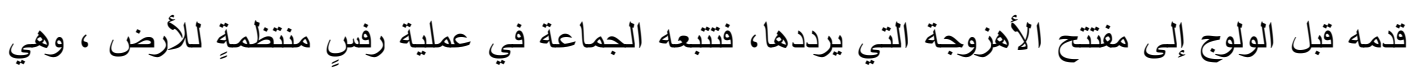

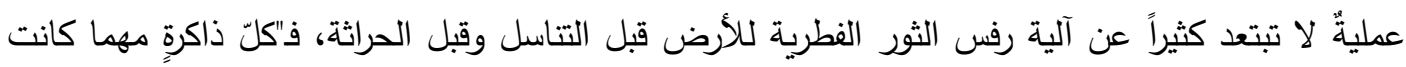

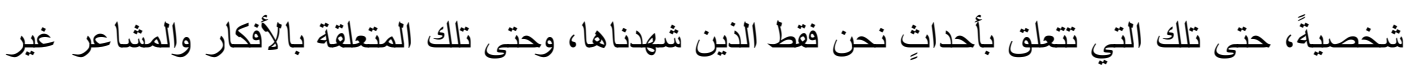

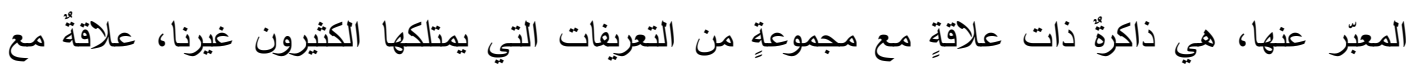

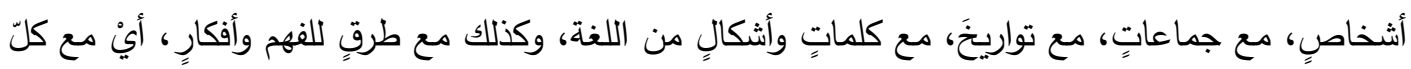

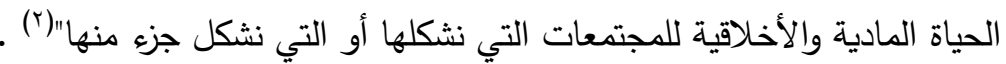

ولو تفحنا تلك الذاكرة الجمعية المشتركة سنجد أن اليهود ذكروا الرقص والمزمار والدفوف بوصفها فعلاً

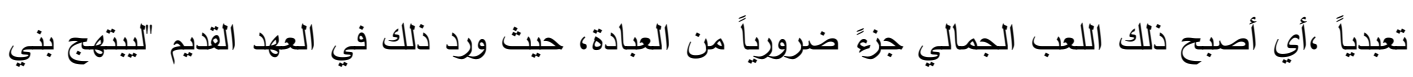

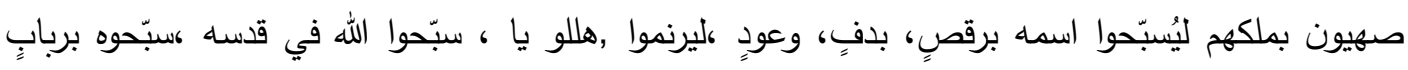

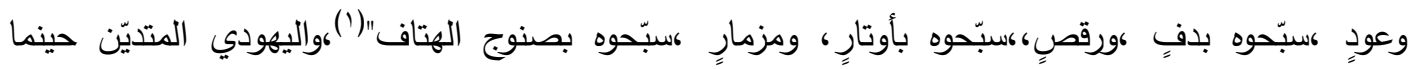

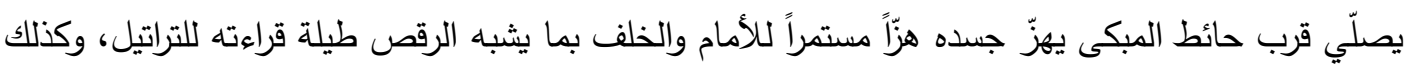

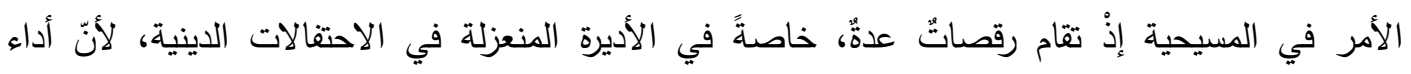

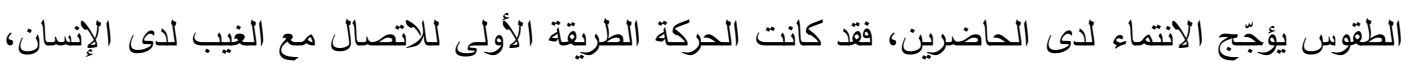

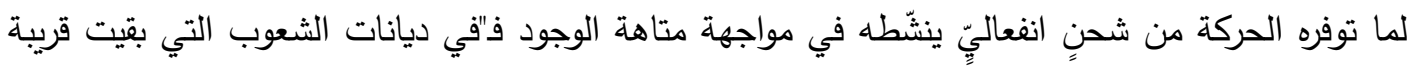

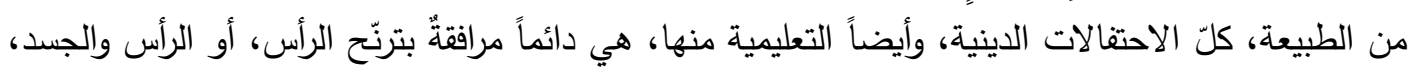

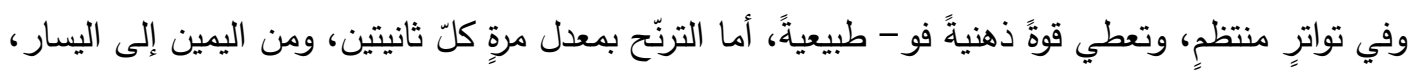

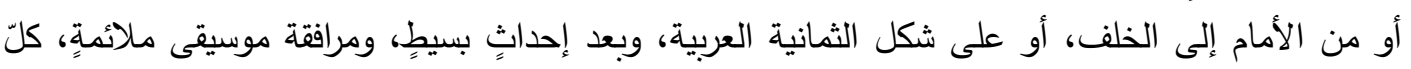

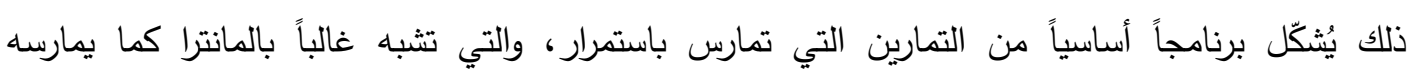

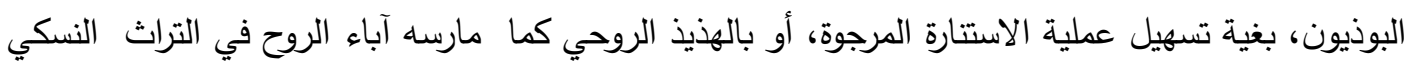


المسيحي"(؟)، ومن المعروف أنّ الصلاة البوذية تشترط الجماعية والموسيقى في أدائها لكونها نتاج حضارة مدينية تُجّد المشاركة والجماعية، على عكس البداوة التي تفترض الفردانية عموماً.

\section{الجسد مفتاحا للسماء}

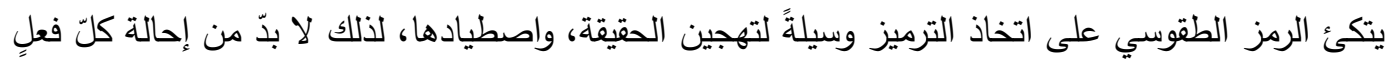

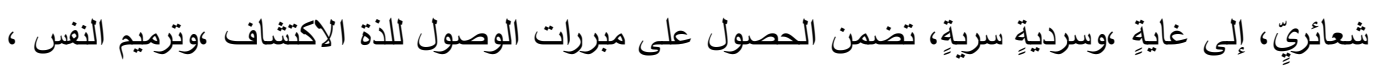

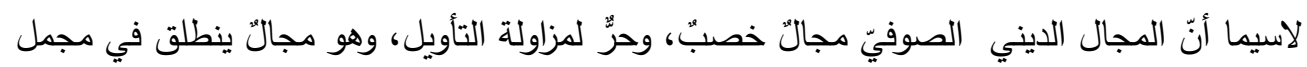

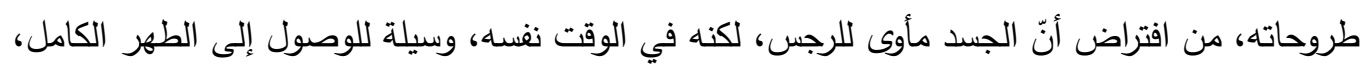

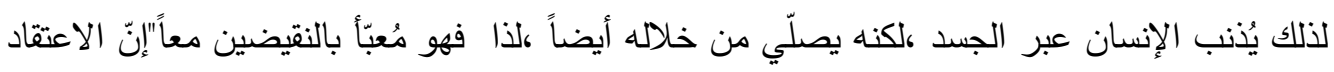

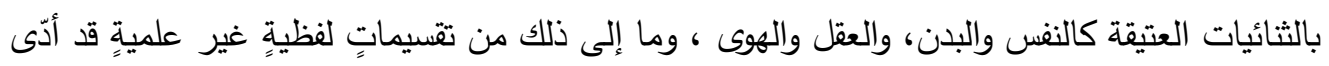

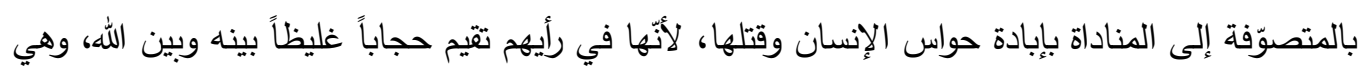

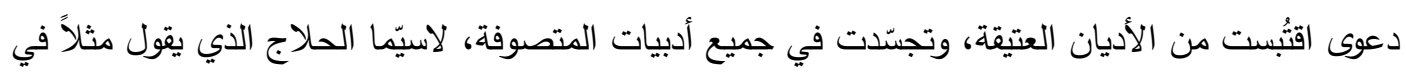
بعض أشعاره:

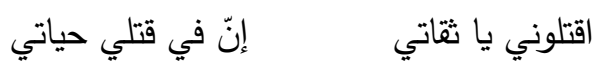

$$
\begin{aligned}
& \text { ومماتي في حياتي وحياتي في مماتي }
\end{aligned}
$$

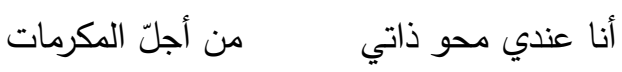

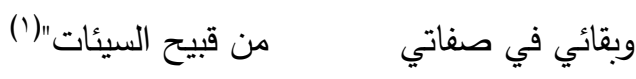

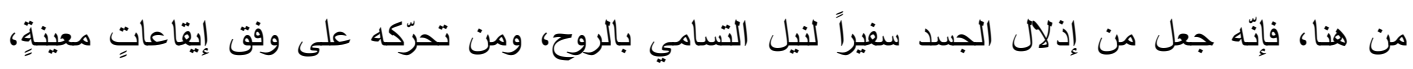

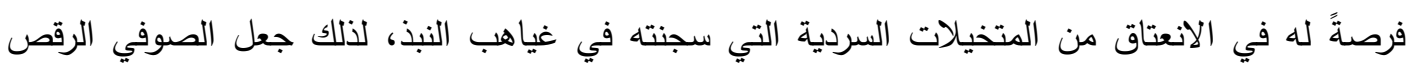

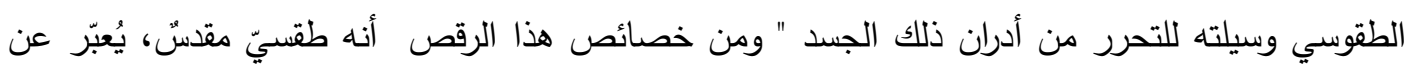

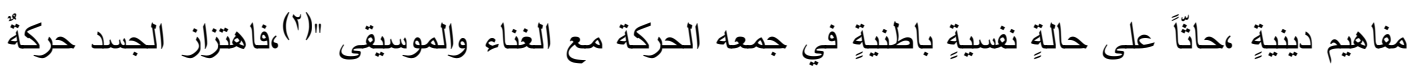

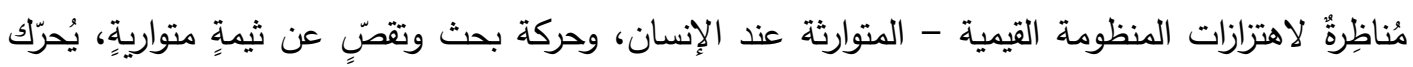

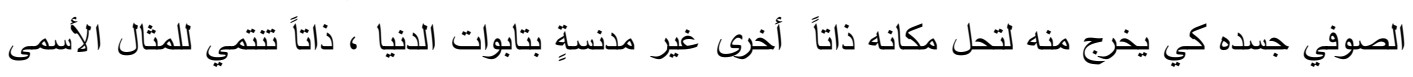

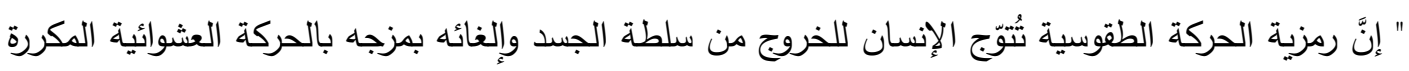

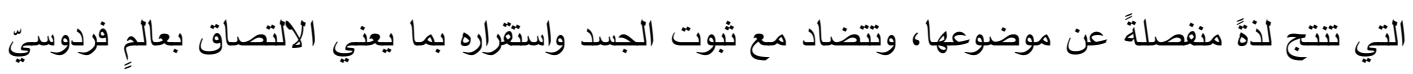

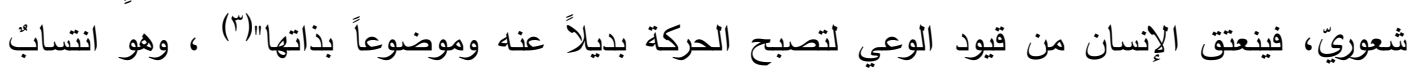

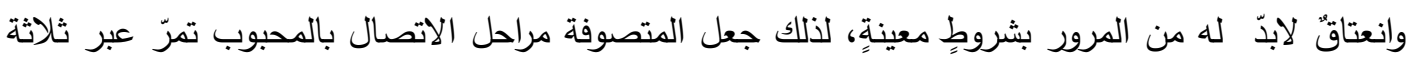
مراحلٍ: التحلي والتخلي ثم التجلي ،وهي مراحل تشتمل على أنواع التجربة الدينية التي ينتقل عبرها الإنسان 
لاكتساب ماهية جديدة و"تثمل الصوفية ثلاث أنواع من التجارب الدينية، الأولى رحلة البحث عن التطوّر

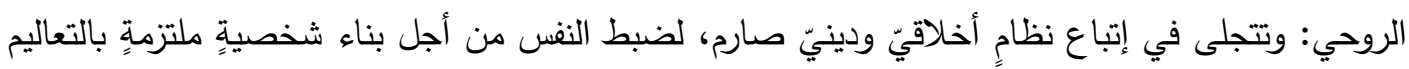

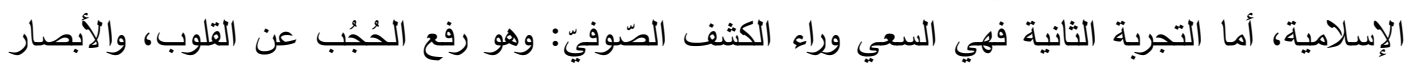

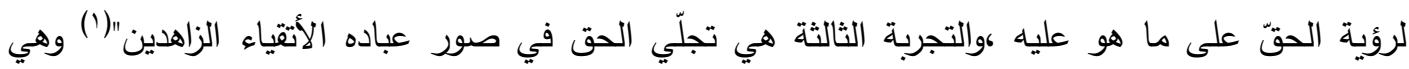

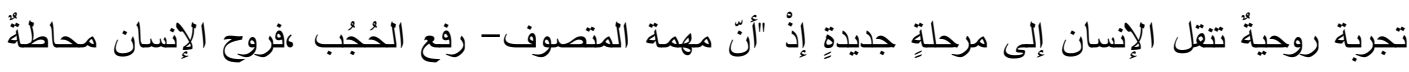

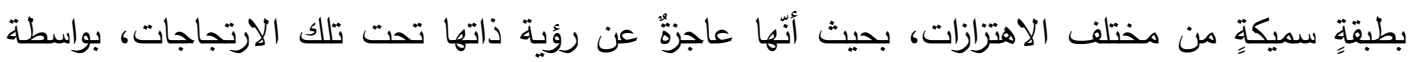

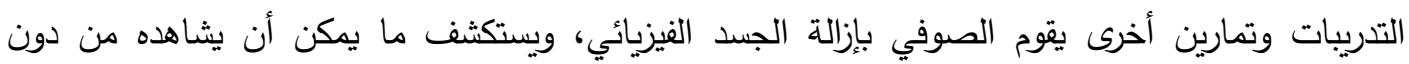

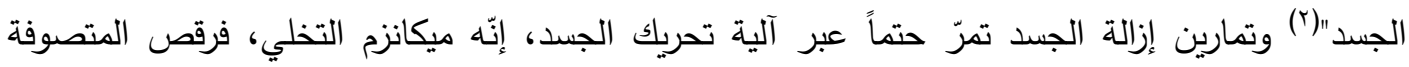

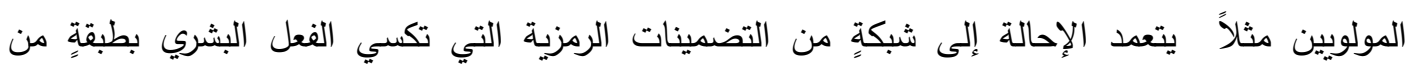

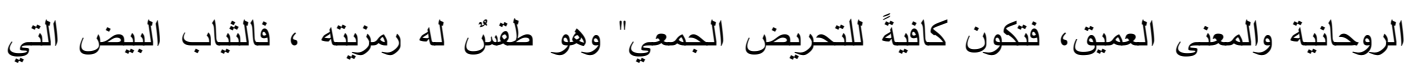

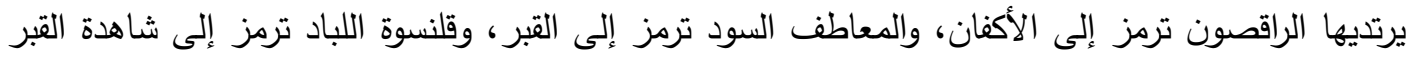

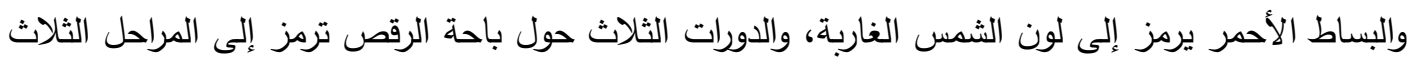

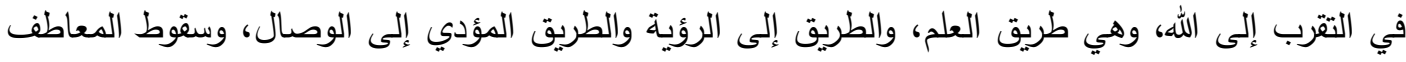

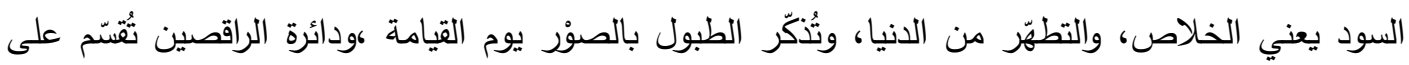

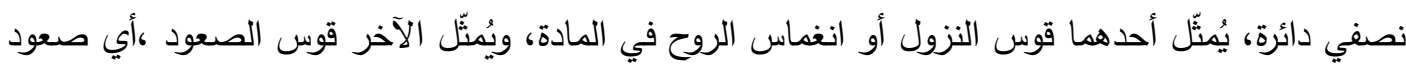

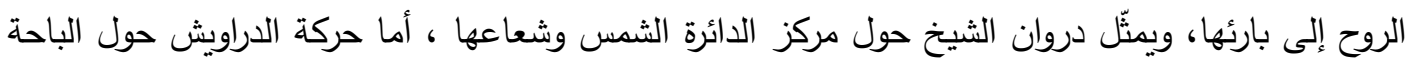

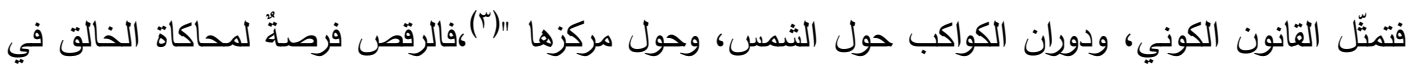

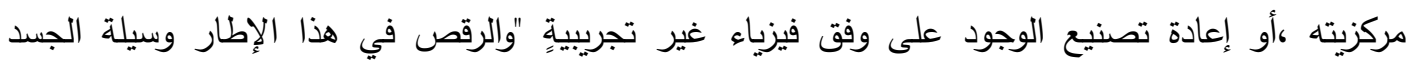

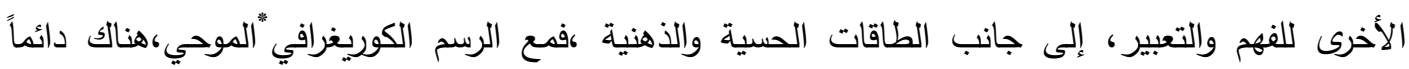

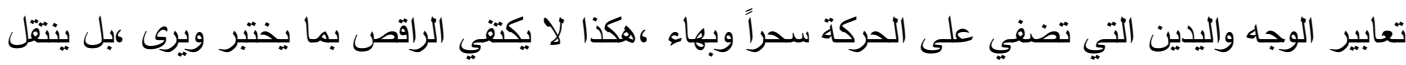

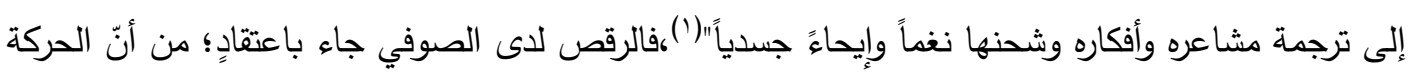

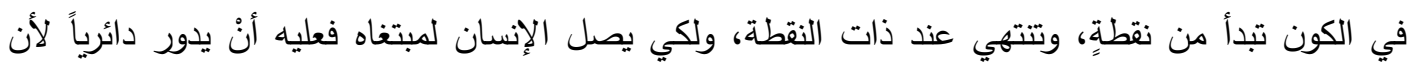

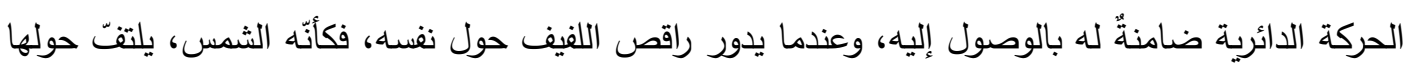

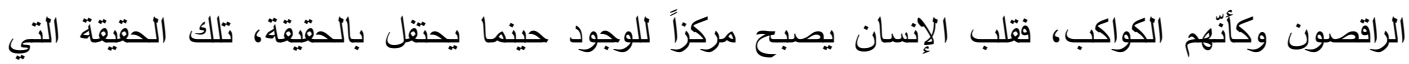

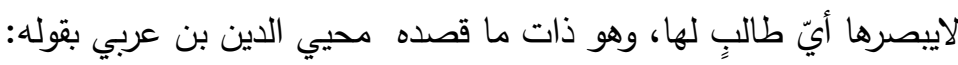




$$
\begin{aligned}
& \text { لقد صلار قلبي قابلاً كلّ صورةٍ فمرعى لغزلانٍ وديرٌ لرهبان }
\end{aligned}
$$

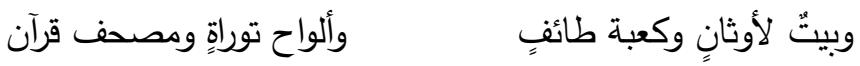

$$
\begin{aligned}
& \text { أدين بدين الحبّ أنّى توجهت ركائبه، فالحب ديني وإيماني (r) }
\end{aligned}
$$

فالله في الفكر الصوفي فكرة، أكثر منه نموذجّ علويّ متواري، لذلك فإنّ هدف الصوفي ليس حضور الإله

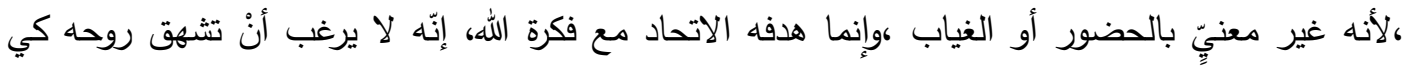

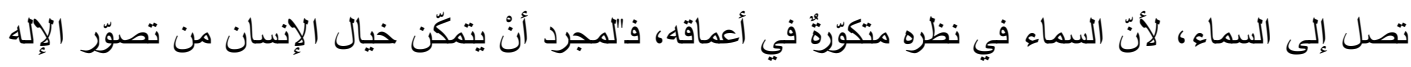

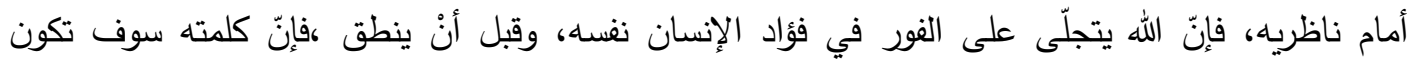

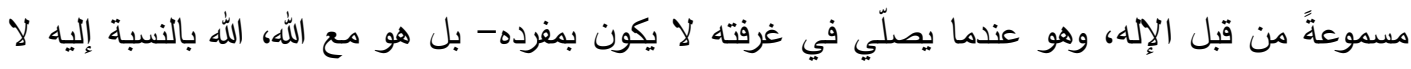

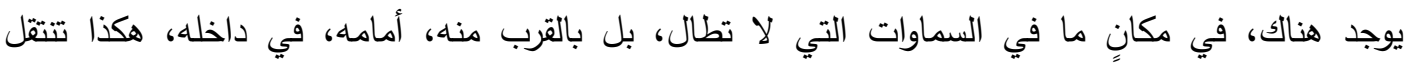

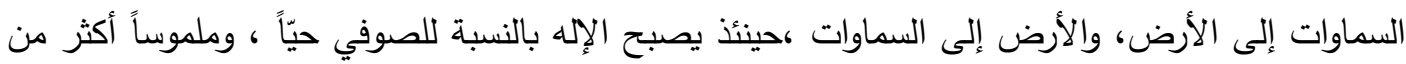

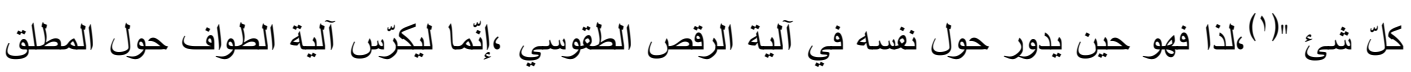

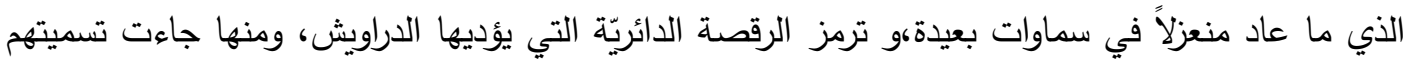

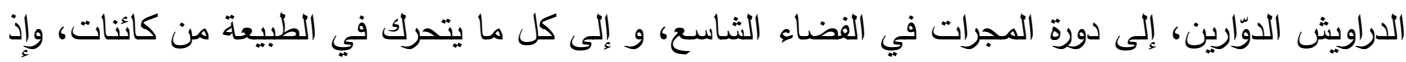

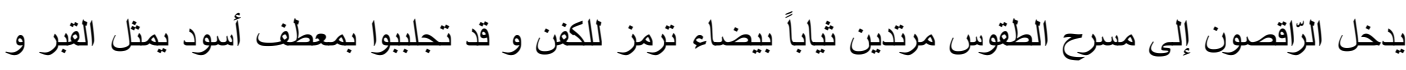

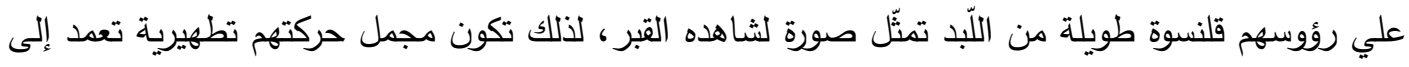
استئناف الحياة بعد مرحلة موت متخيّلة ،ثم يدخل بعدهم الشيخ إلى مركز المسرح ليؤلف القطب الرمزي الذي

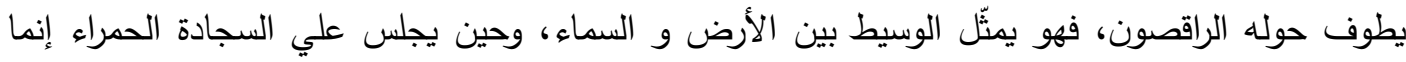

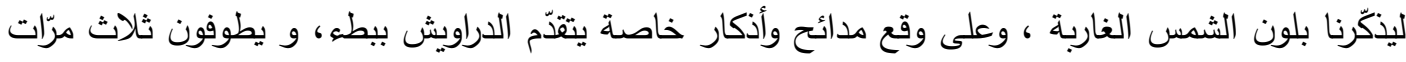

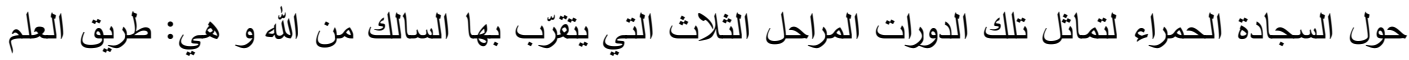

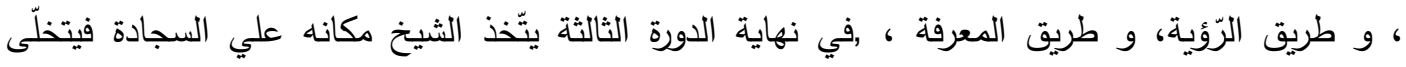

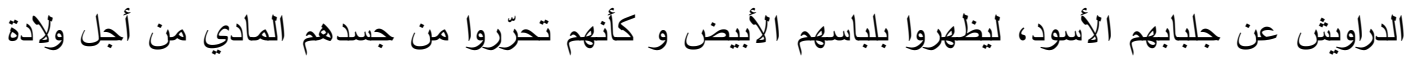

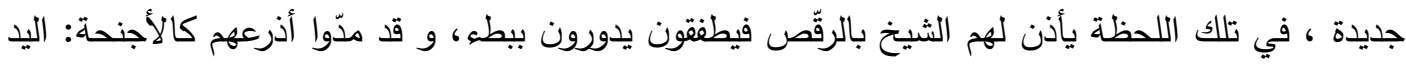

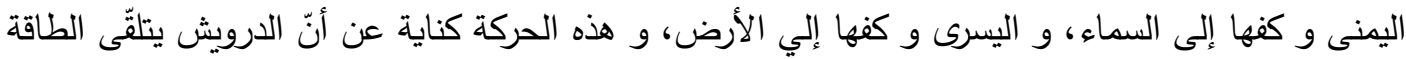

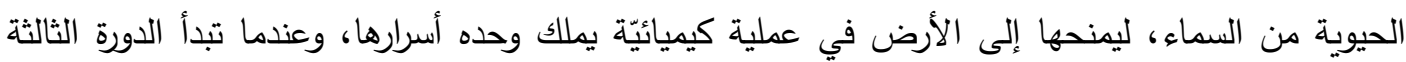

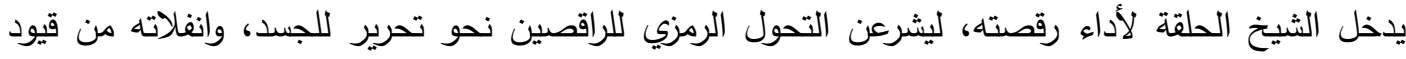




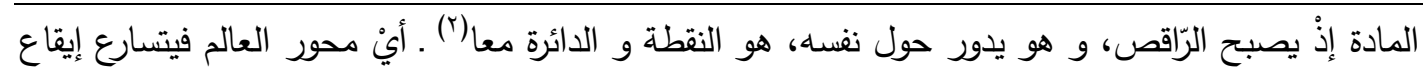

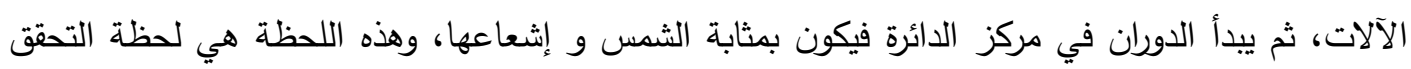

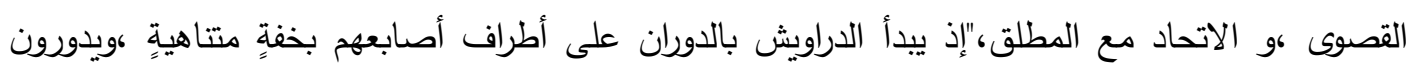

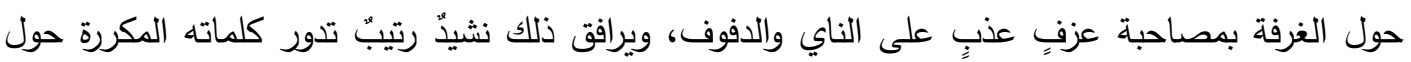

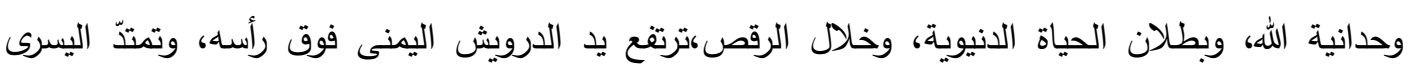

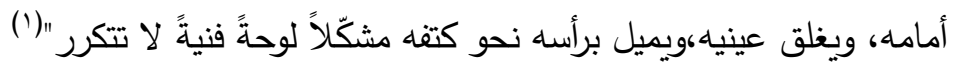

وكلَّ ذلك يجري بمرافقة تراتيل وموسيقى صاخبةٍ و"إذا كان الإسلام الرسمي لا يُحبّّ الموسيقى،فإنّ المتصوفين

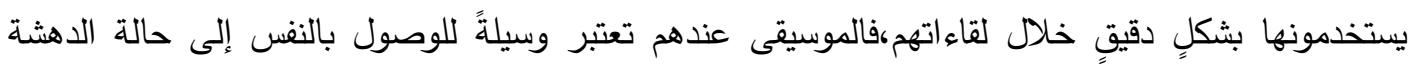

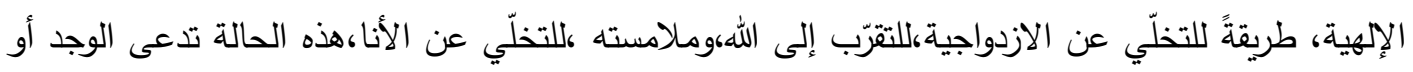

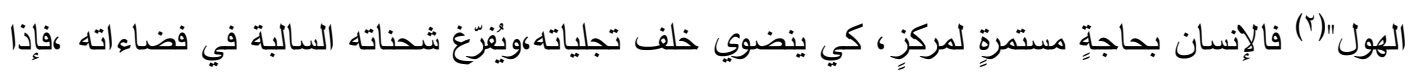

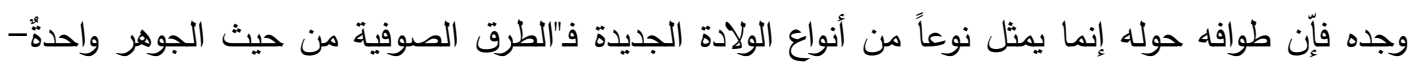

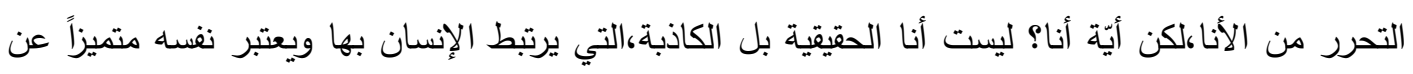

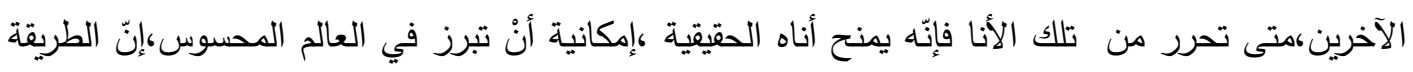

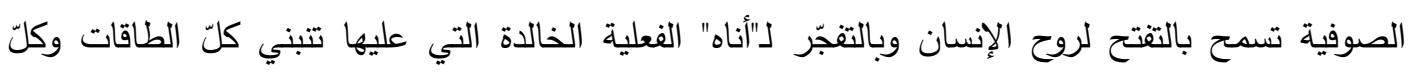

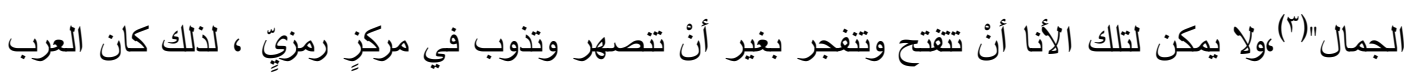

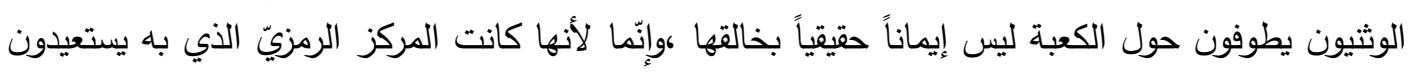

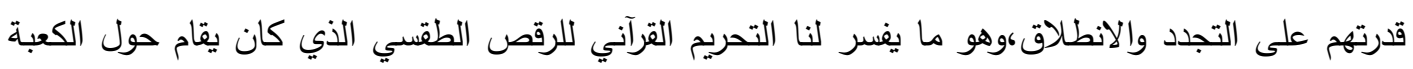

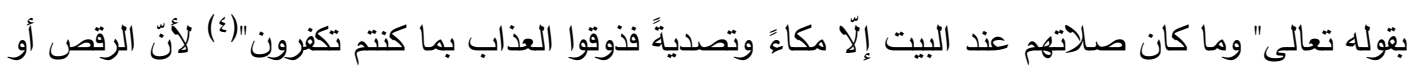

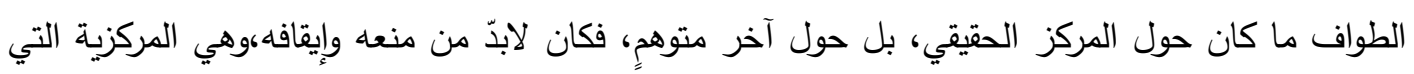

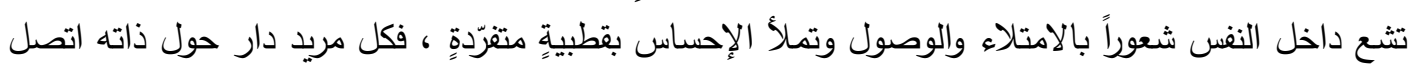

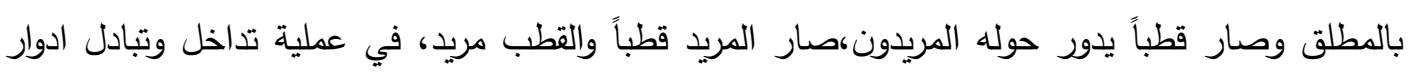
رمزيةٍ مذهلةٍ، وهو ما أشار له جلال الدين الرومي بقوله:

حبّاً بك أسير والرأس مرفوع

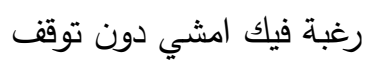

يقولون لي تدور حوله'" جهله! أدور حول نفسي" (1) 


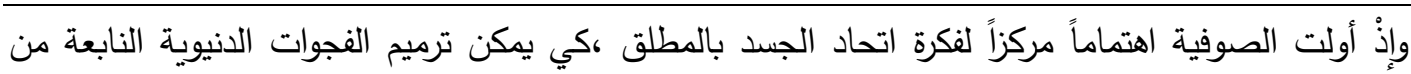

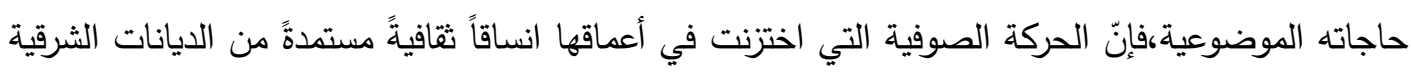

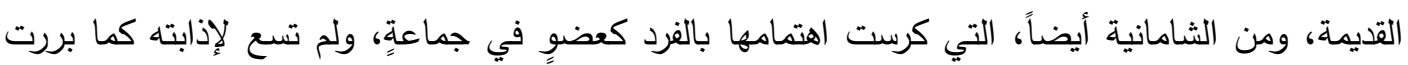

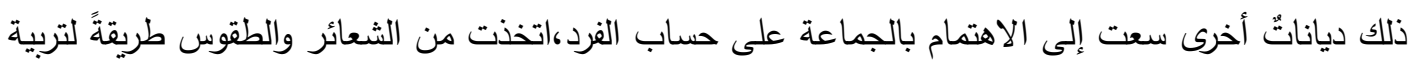

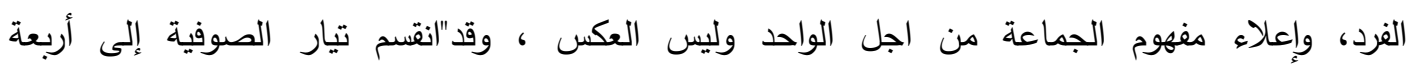

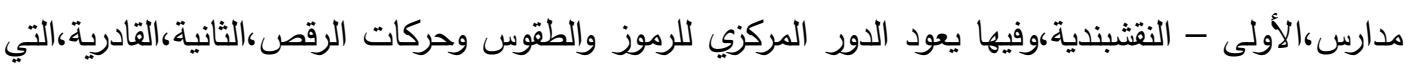

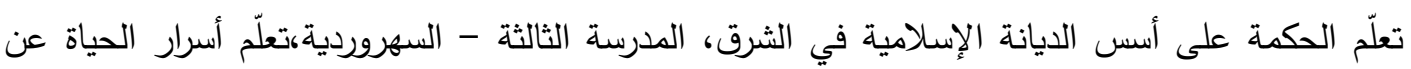

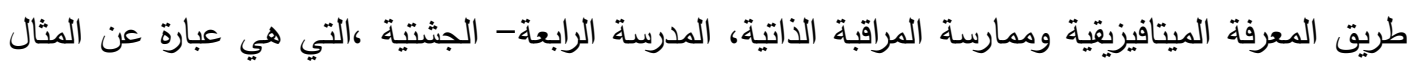

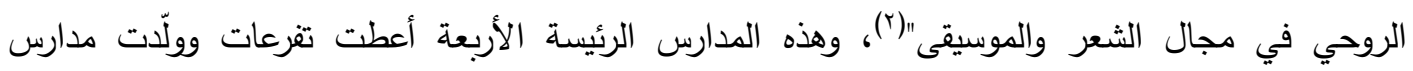

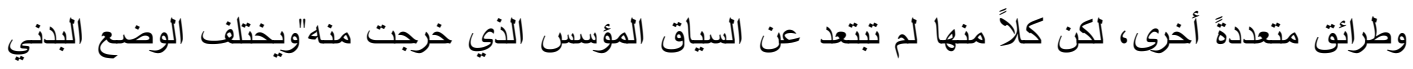

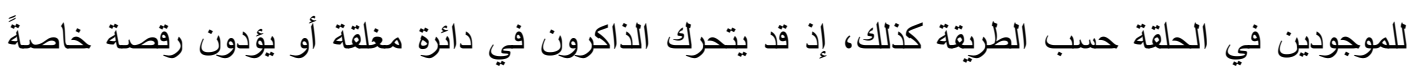

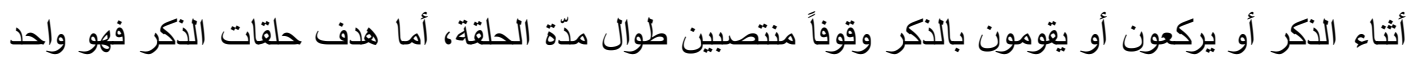

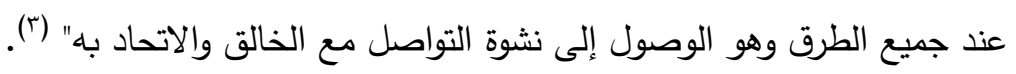

\section{الرقص لغة بصريـة}

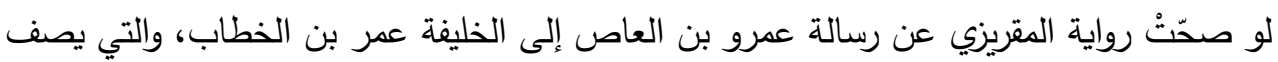

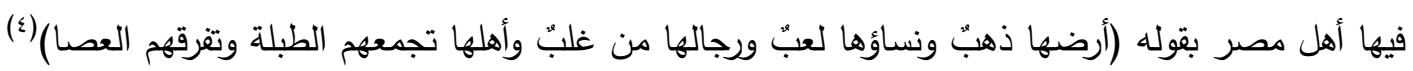

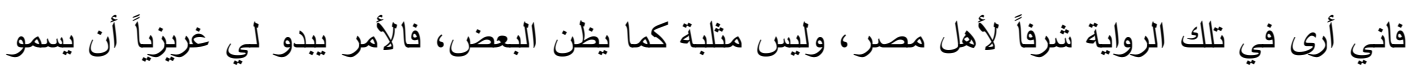

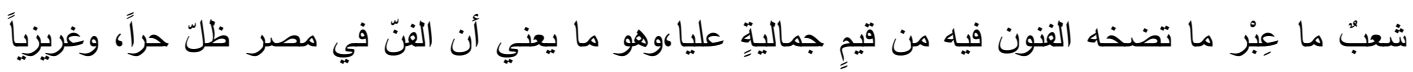

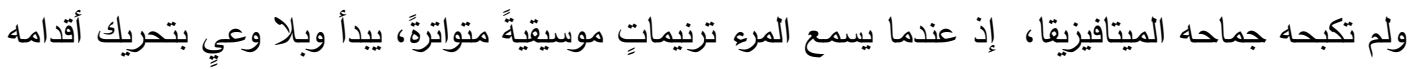

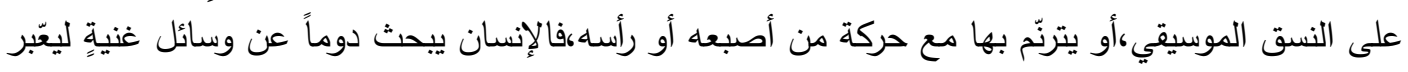

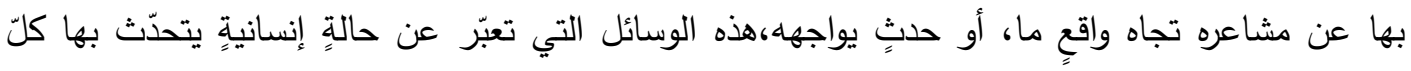

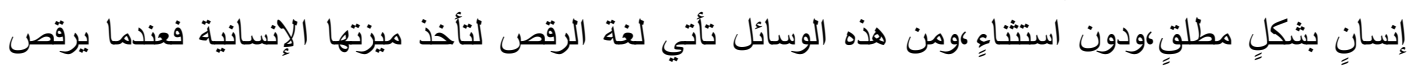

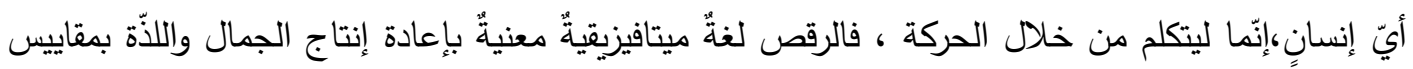

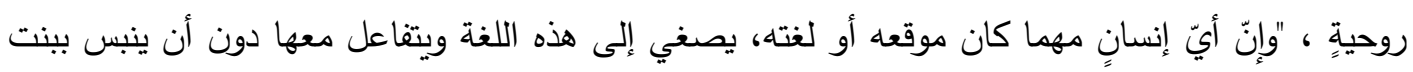


شفة ،ودون أن يسمع لفظاً واحداً، ثمة لغة لا يمكن التعبير عنها إلا بلغة الرقص، ولذلك نرى مختلف شرائح

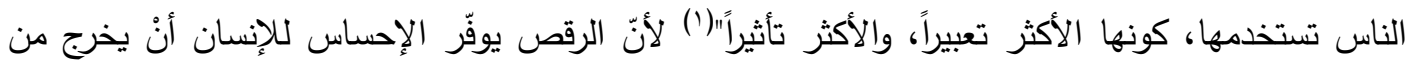

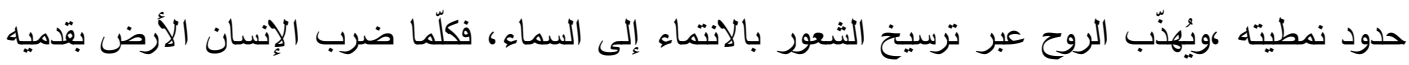

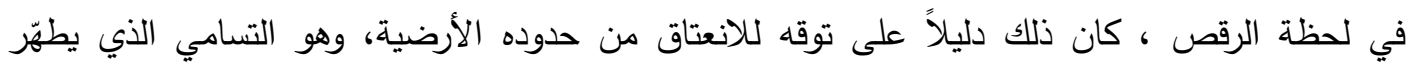

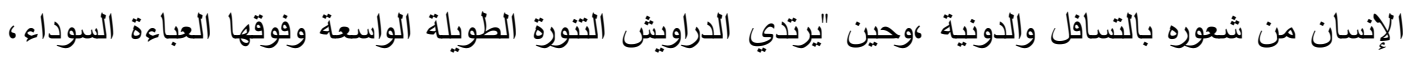

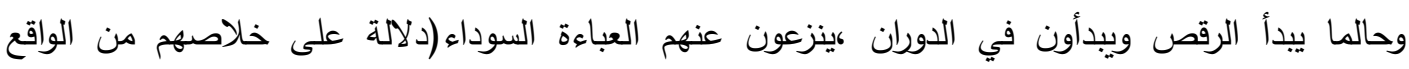

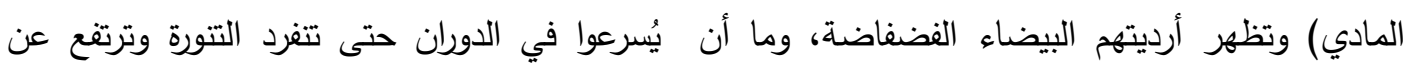

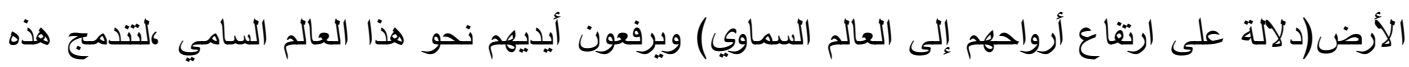

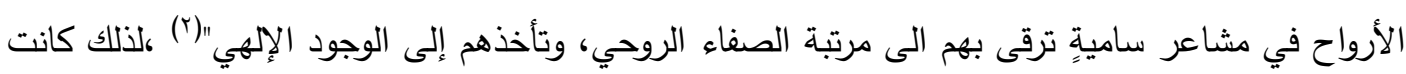

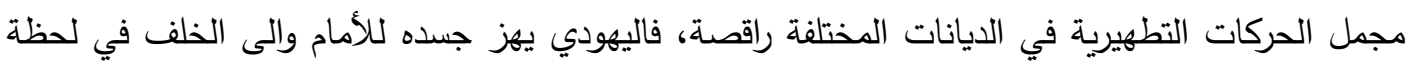

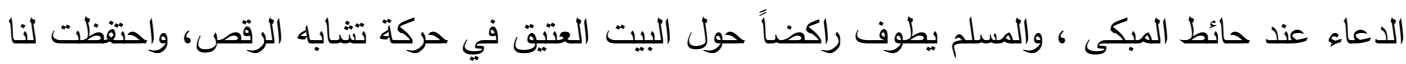

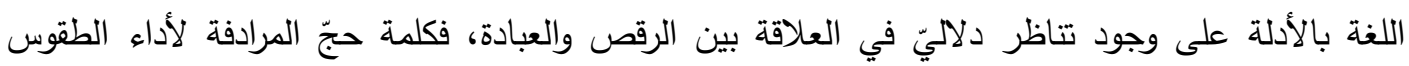

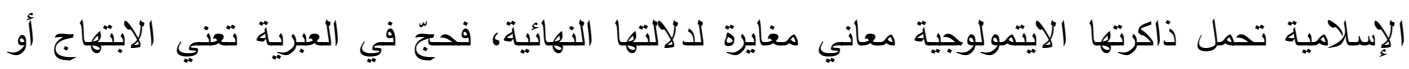

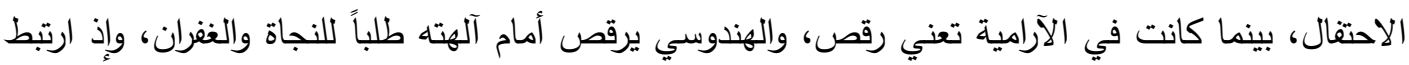

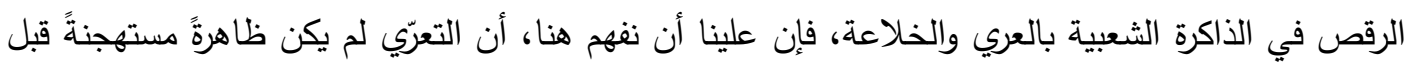

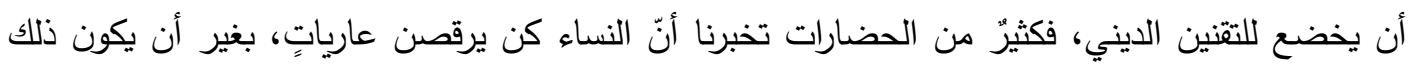

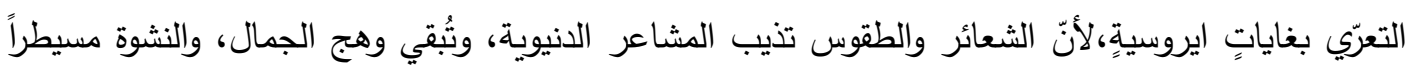

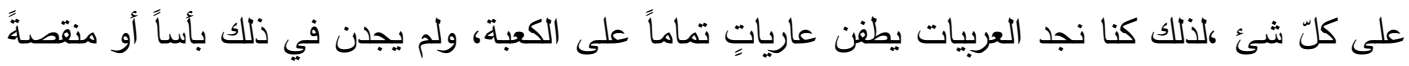

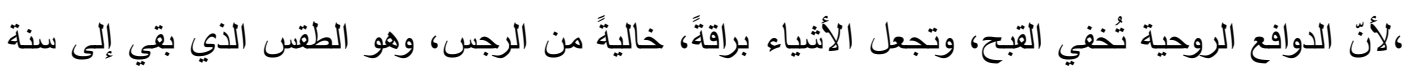

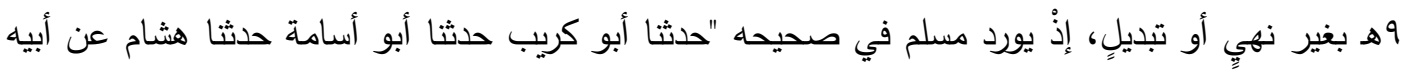

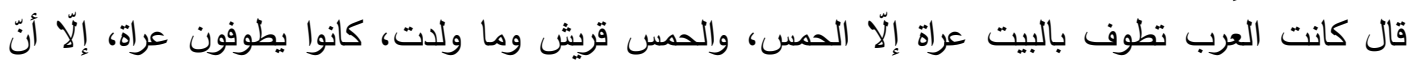

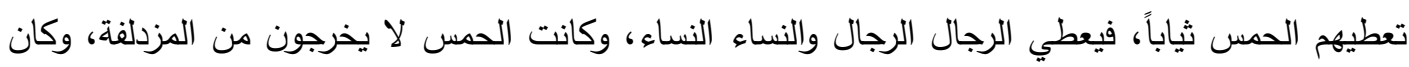

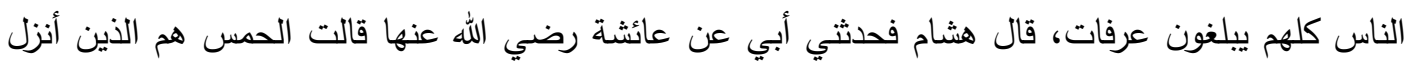

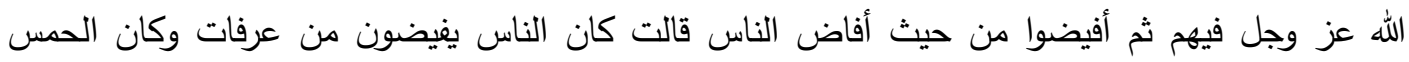

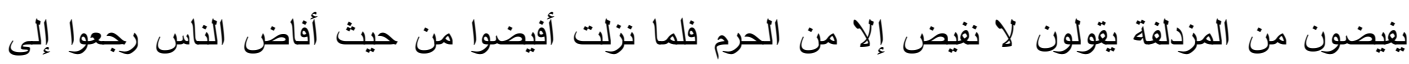

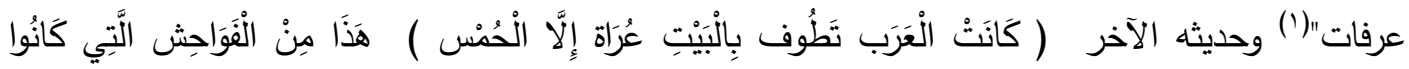

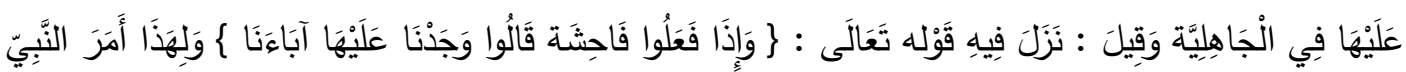




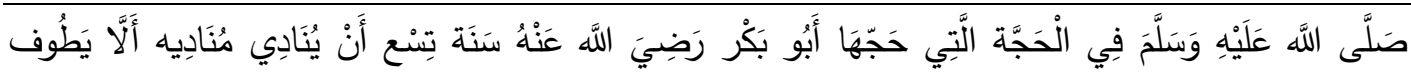

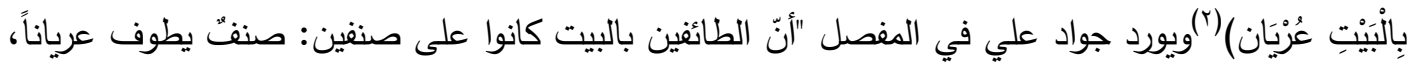

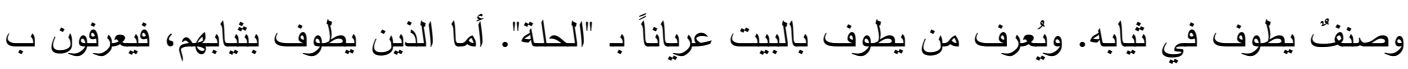

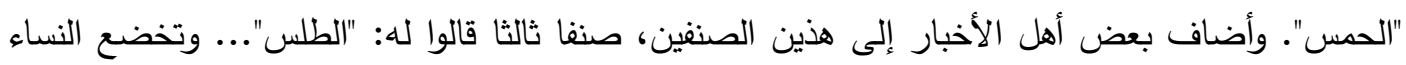

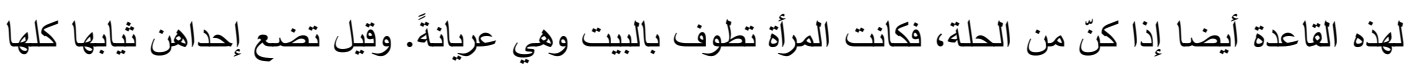

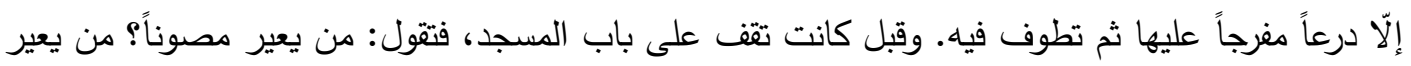

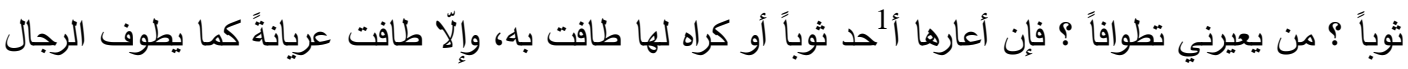

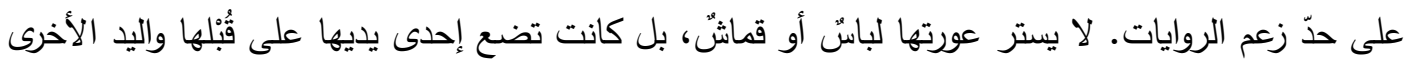

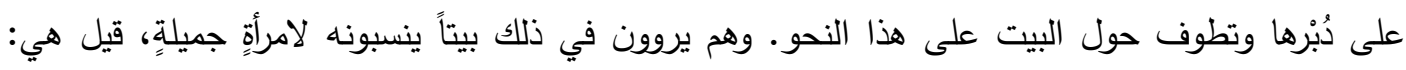

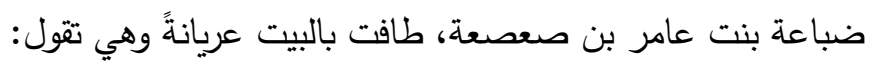

\section{اليوم يبدو بعضه أو كلّه وما بدا منه فلا أحلّه"(')}

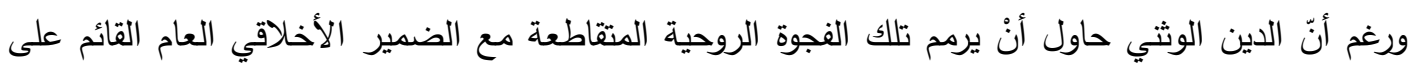

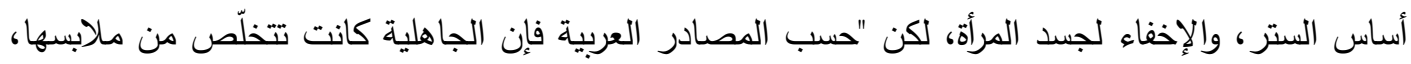

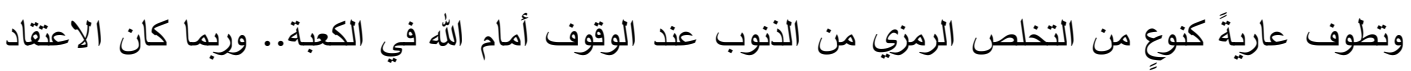

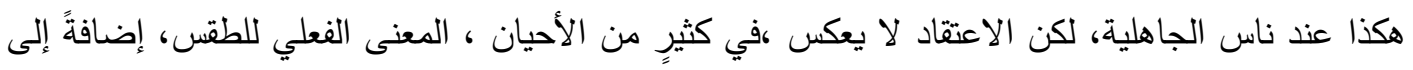

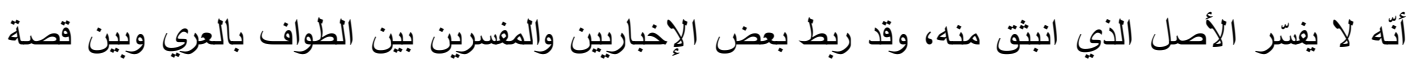

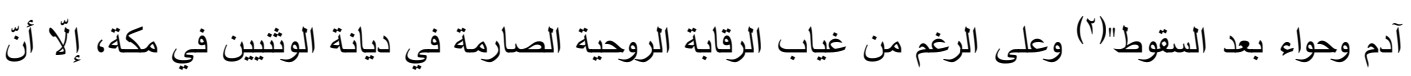

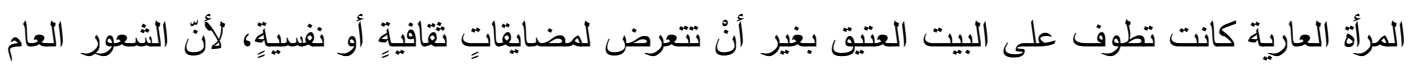

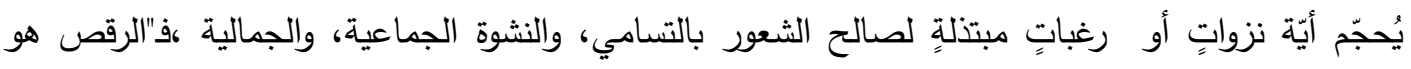

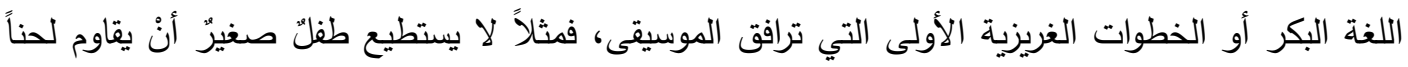

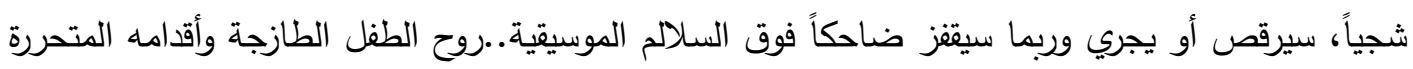

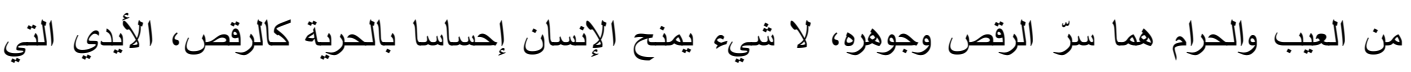

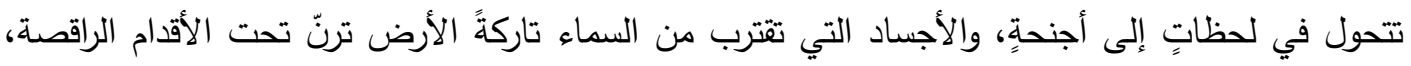

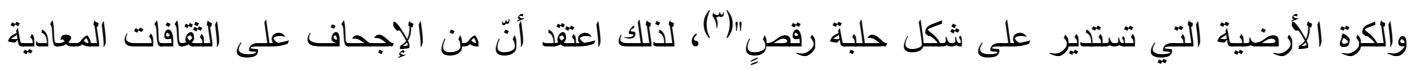

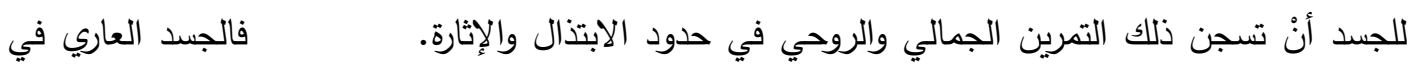

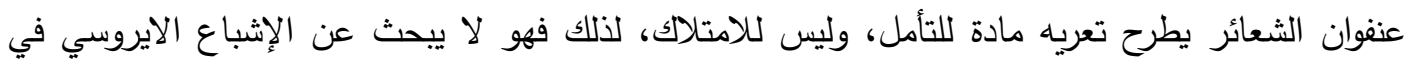


رحلة حركته الدكررة والجماعية، بقدر ما يبحث عن اليقين الذاتي ،فهو يُجرّد ممتلكاته مما يغطّيها، لكي يلتّّ

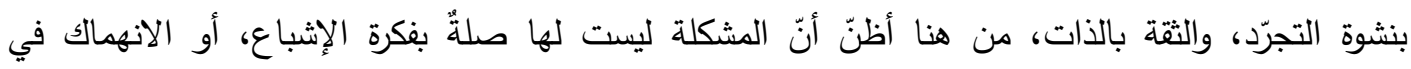

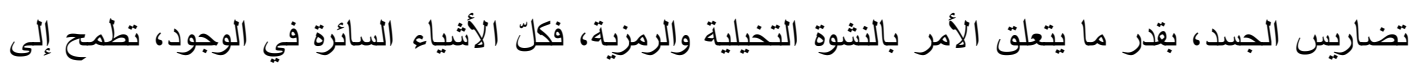

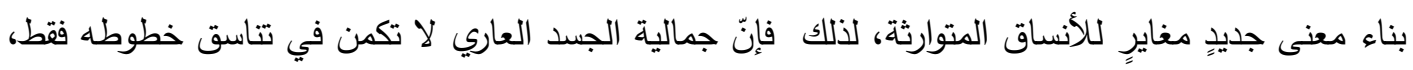

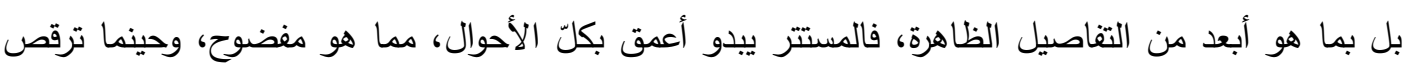

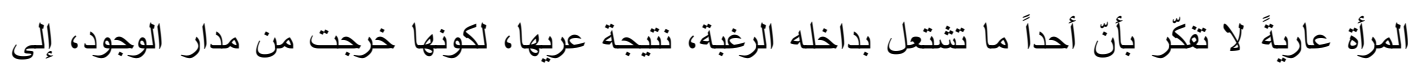

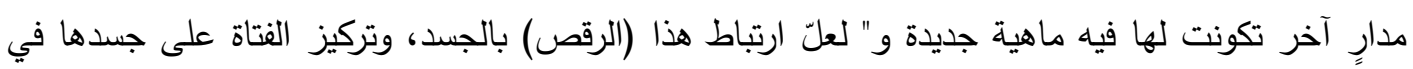

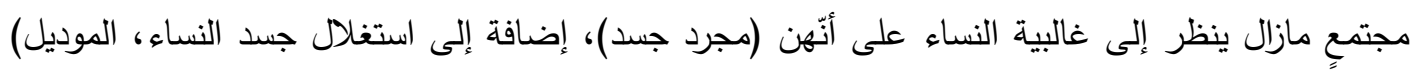

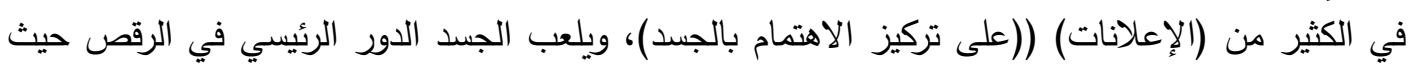

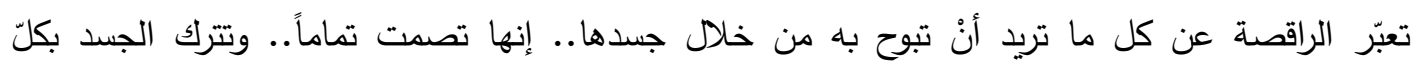

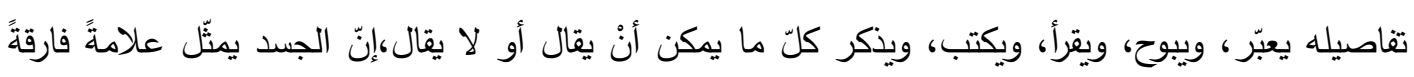

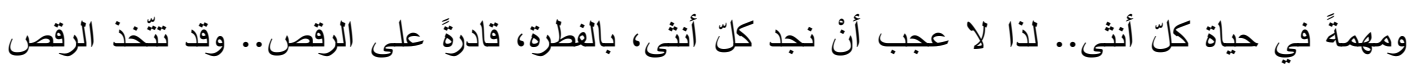

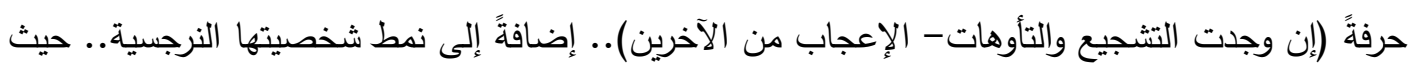

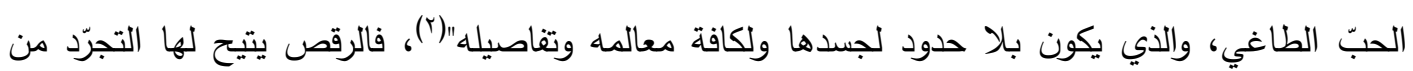

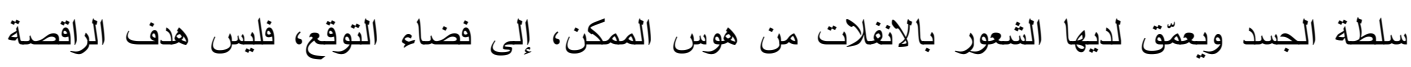

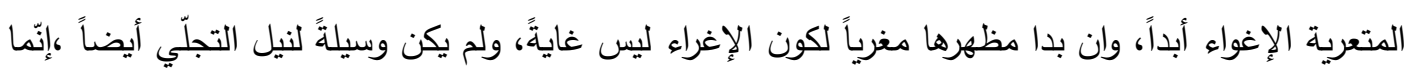

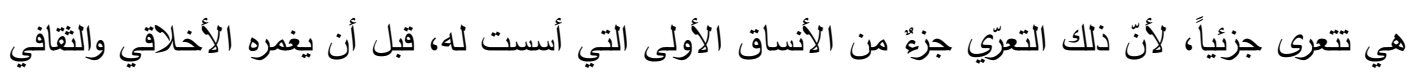

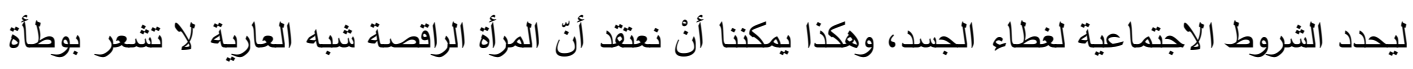

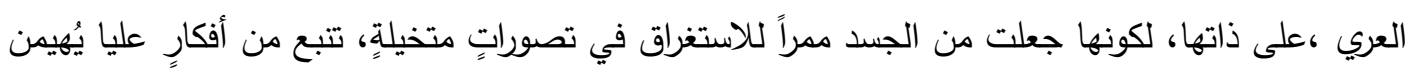

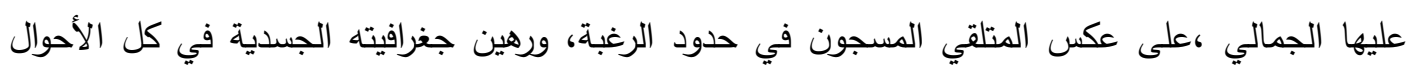
والذي لم يتخْ المجال لجسده أن يتحرر من سجون المعنى وظلّ أسيراً للتصورات المتخيلة المتوارثة، فأصبح

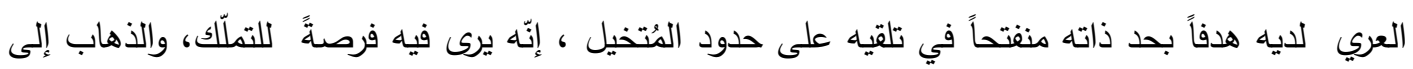

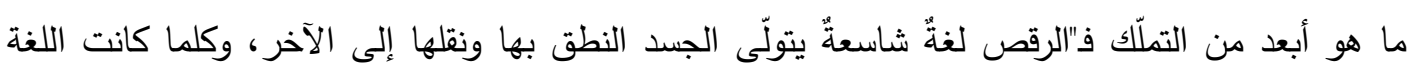

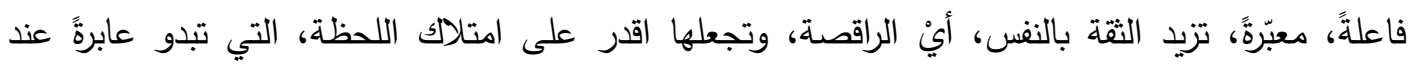

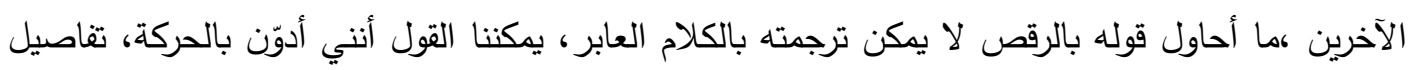

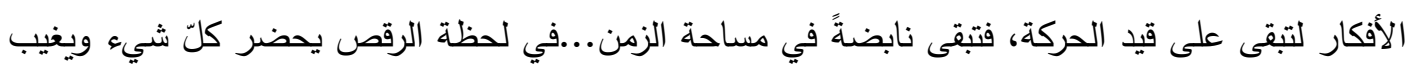


كلّ شيء، تصبح اللحظة مثل كيانٍ مفاجئ، كيانٍ يحتوي قوة الحياة وعذوبتها ،وفي الوقت نفسه يجعلك ترى

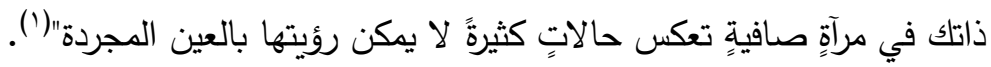

\section{الطقوس وآليات تحرر الجسد}

تأسّس الرقص في بواكير نشوئه ليكون معادلاً موضوعياً للصلاة ، إذْ حين تعجز اللغة عن ترجمة

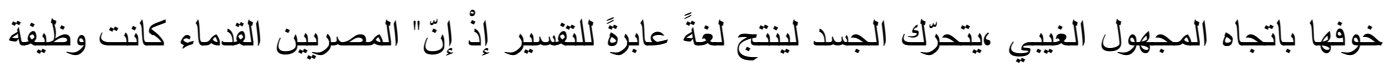

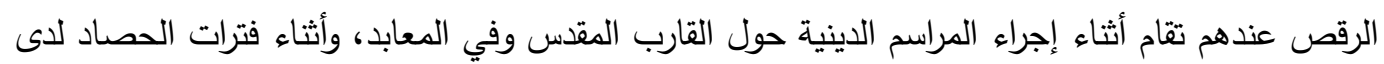

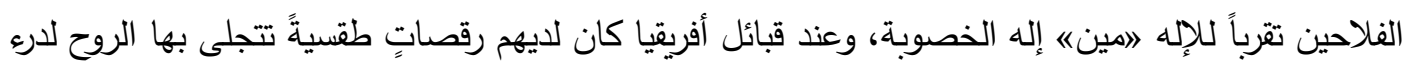

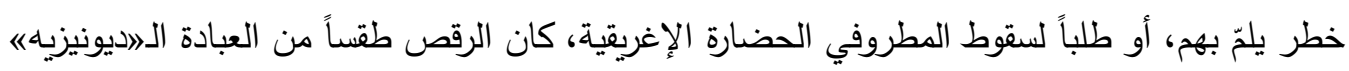

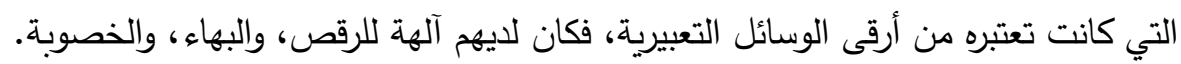

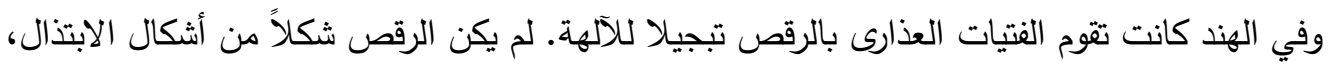

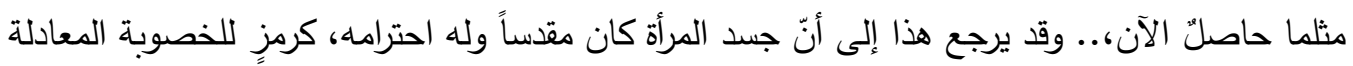

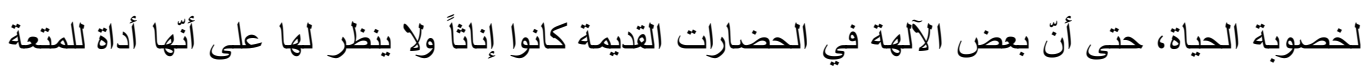
وإثارة الغرائز "(r).

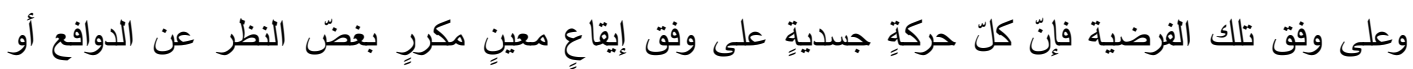

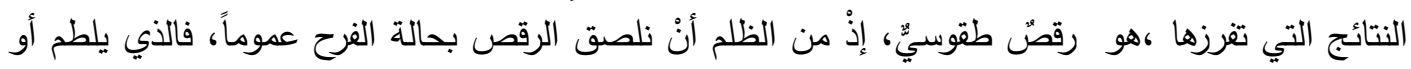

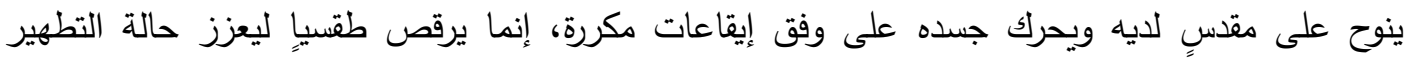

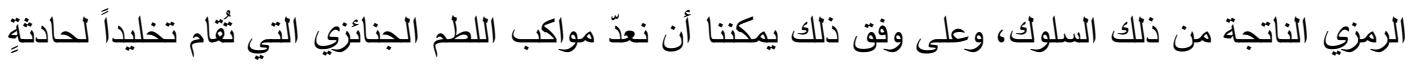

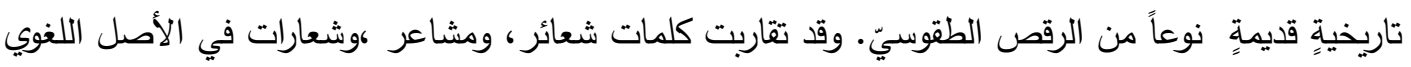

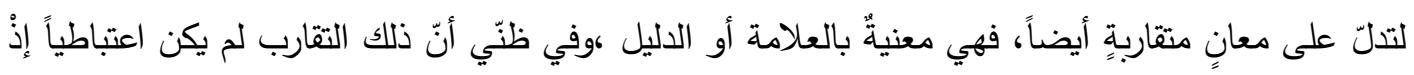

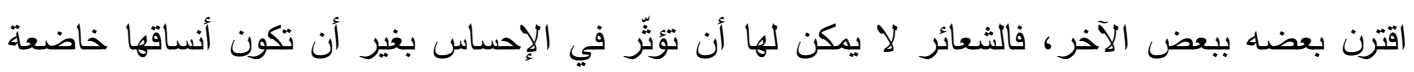

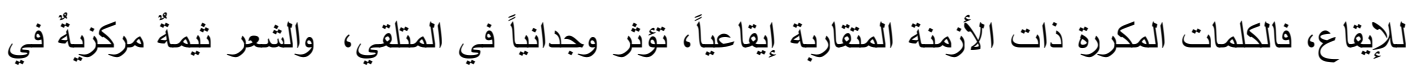
الأداء التعبيريّ للشعائر والطقوس ،وكذلك لا تخلو من الثحنات الانفعالية لأنّ مجالها الوجدان ،ذلك أنّ كلّ التّات

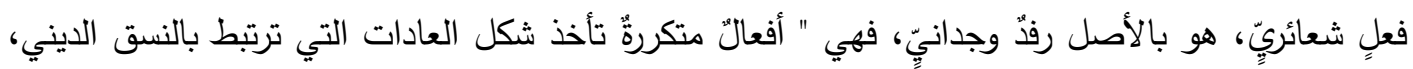

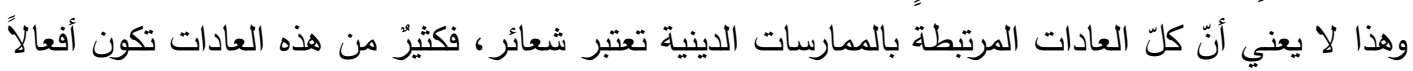

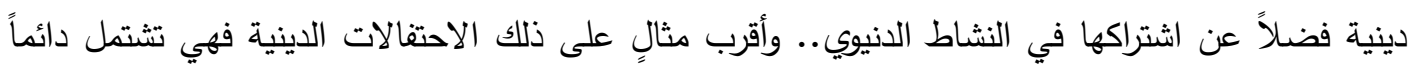
على الجانبين، الثعائري والدنيوي.. وهذا يعني أنّ الثعائر مهما كانت بسيطةً أو معقدةً، جماعيةً أم فرديةً 
تعتبر ترجمةً وأداءً للاعتقاد"(r)،ويرى محم الطاهر بن عاشور أنّ"الثعائر : جمع شعيرةٍ: المعلم الواضح مشتقةً من الثعور ، وشعائر الله :

لقبّ لمناسك الحج ، جمع شعيرةٍ بمعنى: مشعرةٍ بصيغة اسم الفاعل أيْ معلمة بما عينه الله "((").

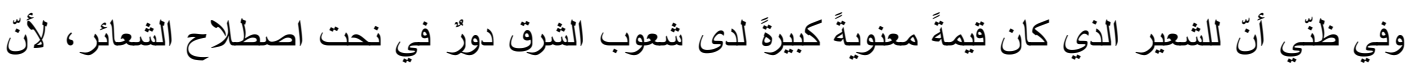

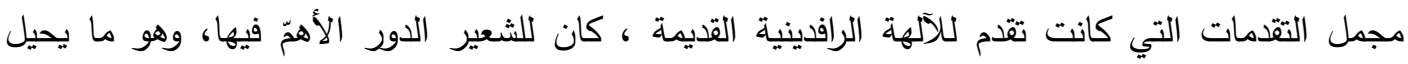

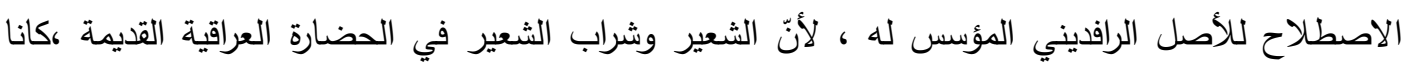

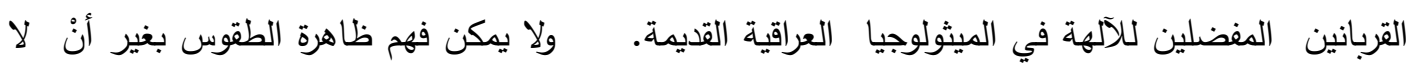

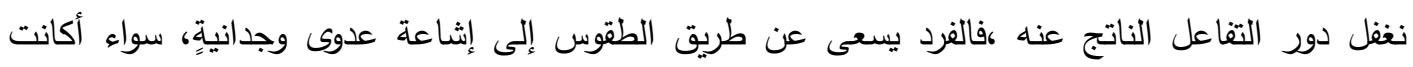

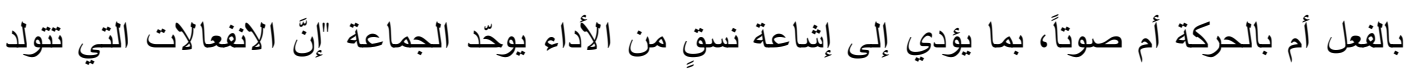

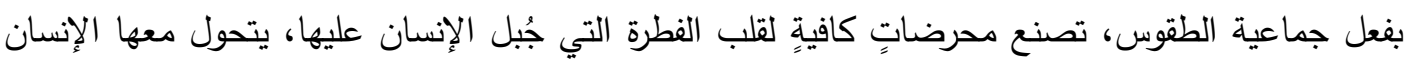

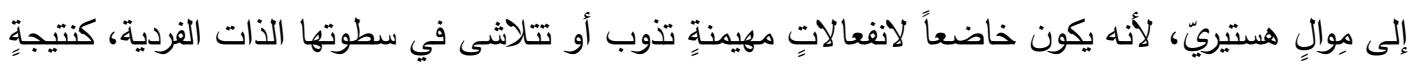

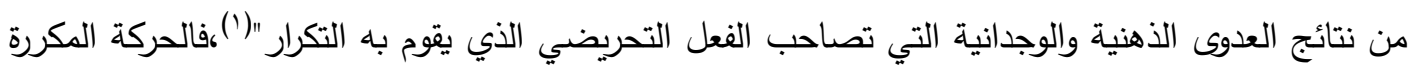

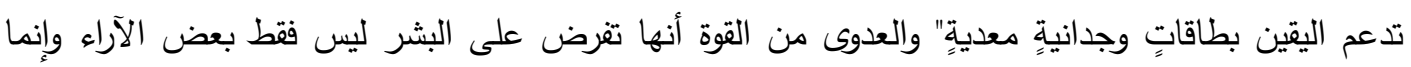

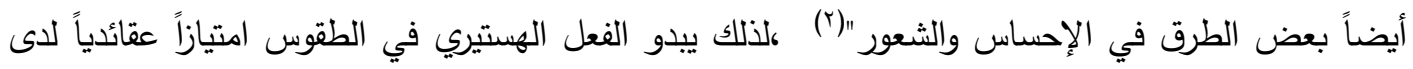

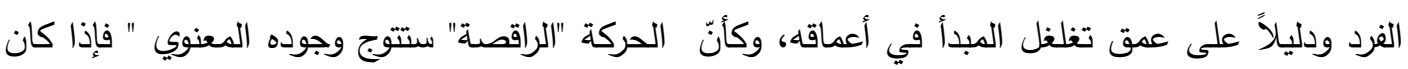

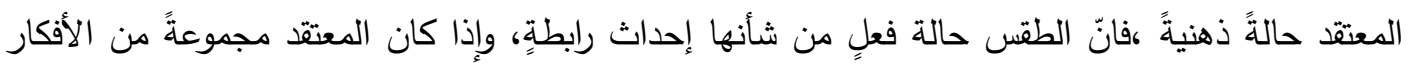

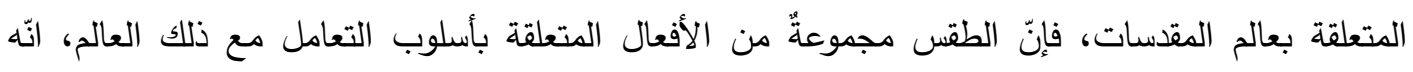

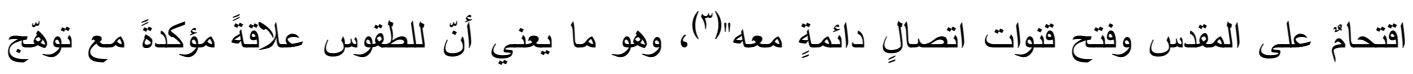

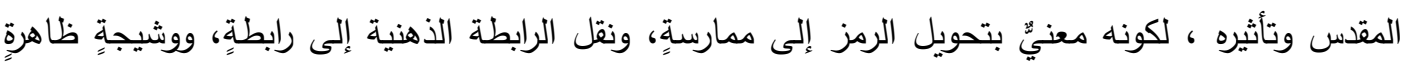

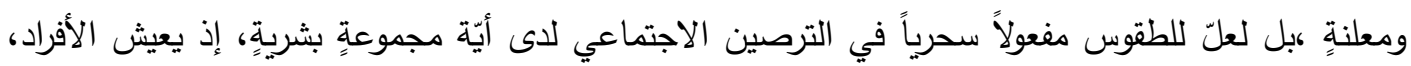
حيث هم أفرادٌ، لذواتهم الفردية، و لكنّهم عندما ينخرطون في الأنشطة الاحتفالية الطقوس الجماعية، دينيةً

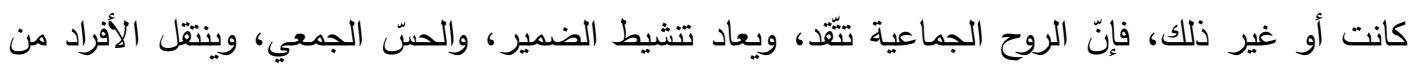

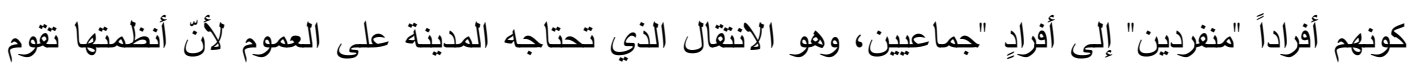

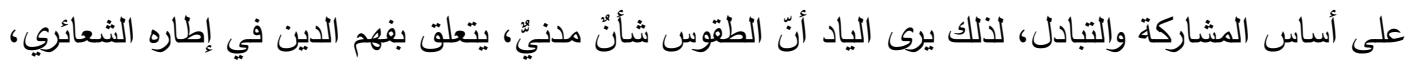

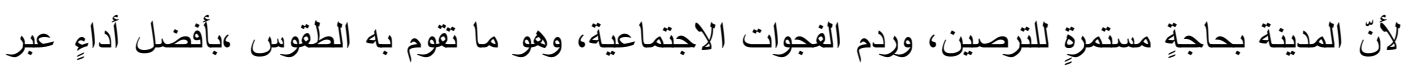

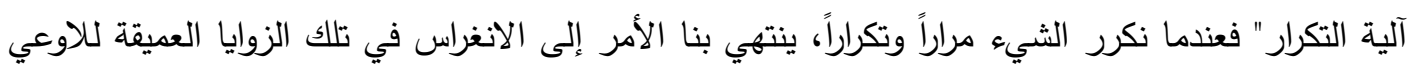

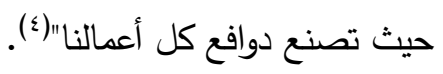


إنّ الخبرة التي تصنعها الطقوس في علاقتها مع الدين داخل الجماعة، تأخذ بُعدين: "الأول جماعيّ يتمثّل في

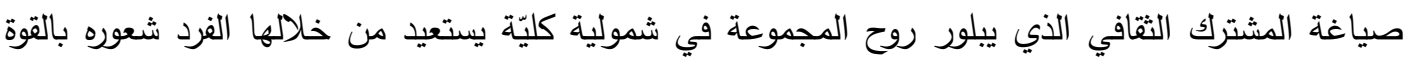

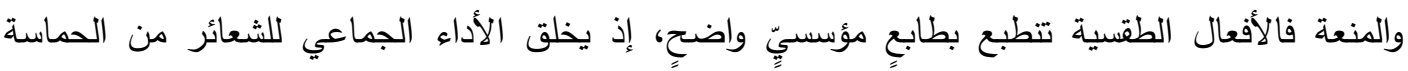

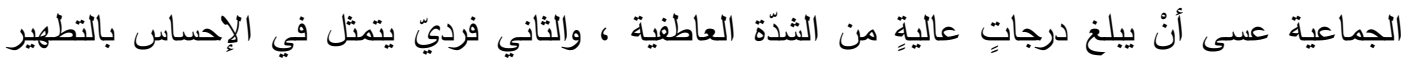

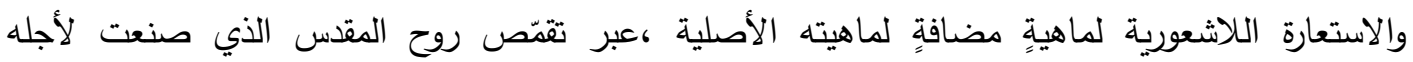

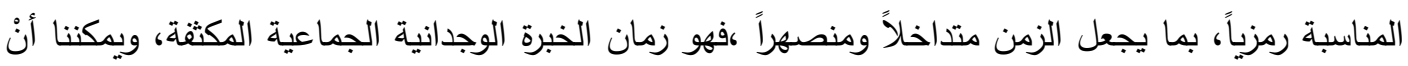

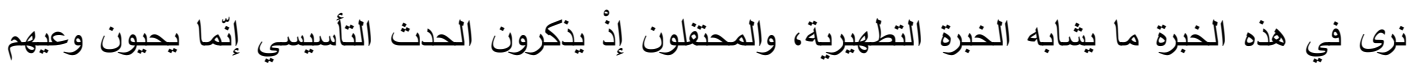

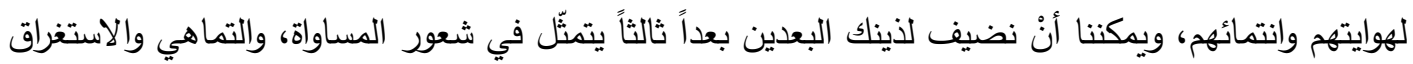

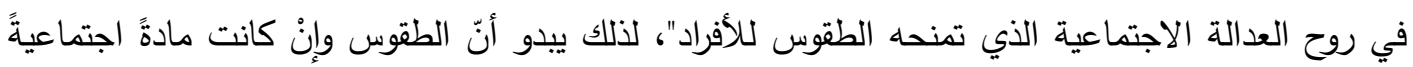

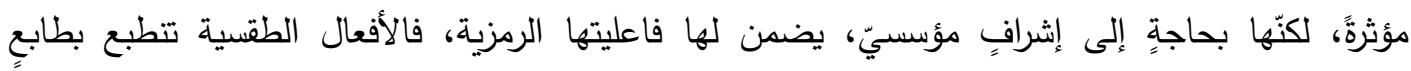

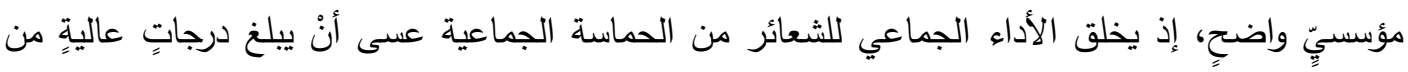

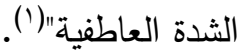
وتعدّ اللذة التي تتتج عن الأداء الحركي للجسد غير نهائية وْفهي مرتبطة أساساً بإنتاج العمى الذهني، وما

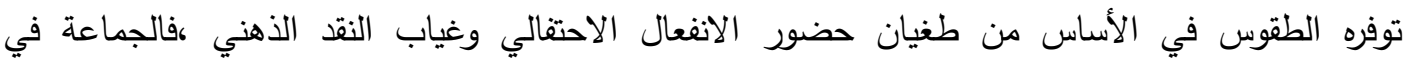
محطاتها الثعائرية غير معنية بالجذوى العقائدية بقدر عنايتها بالتراصّ الاجتماعي ،واللذة الككتسبة بنتيجة

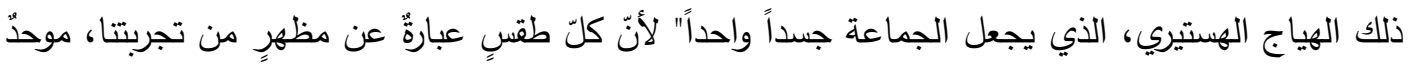

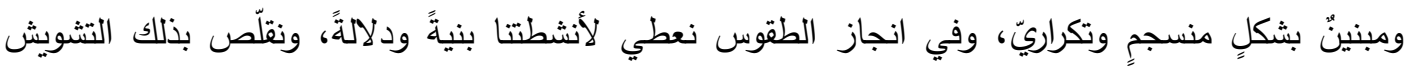

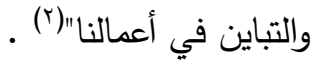




\section{الرقص الطقسي رسالة ثقافية}

مثلما كانت الوقائع الثقافية خمائر متحررةً، في أعماق كلّ جماعةٍ بشريةٍ، وبما يؤثرّ في بلورة أنماط

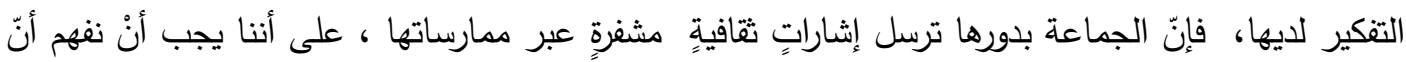

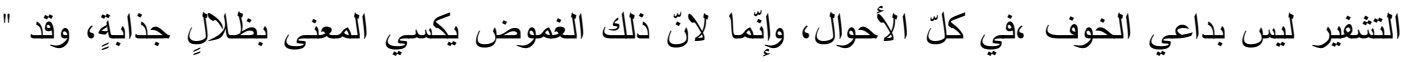

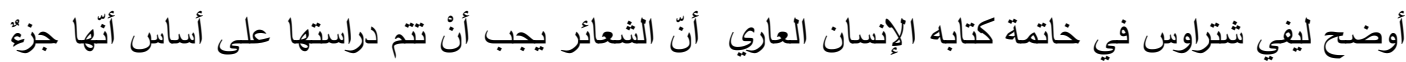

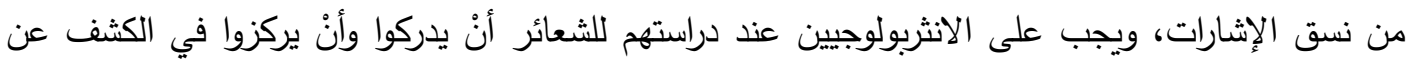

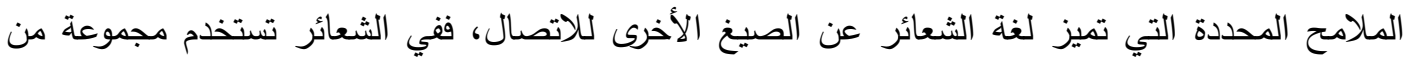

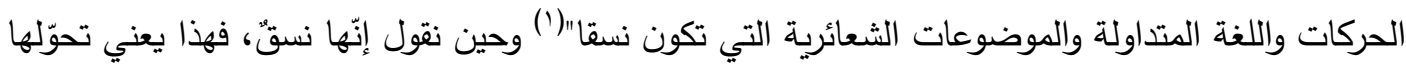

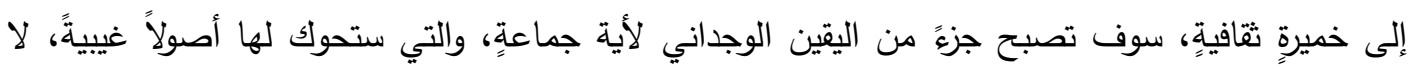
يمكن الطعن في جدواها بمجرد أنْ تصبح نسقاً.

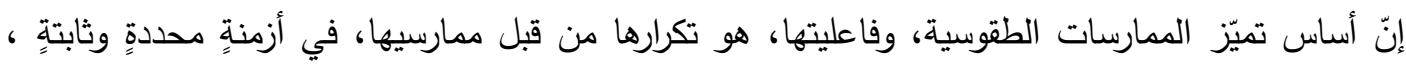

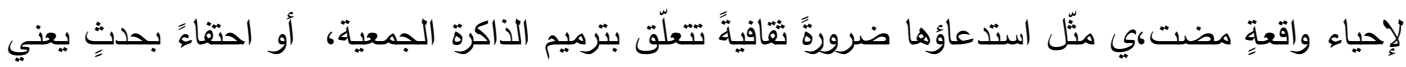

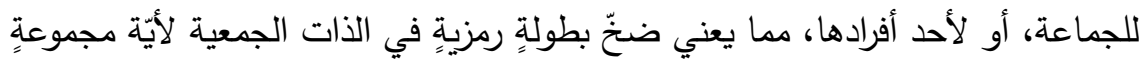

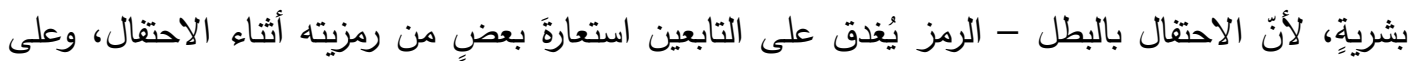

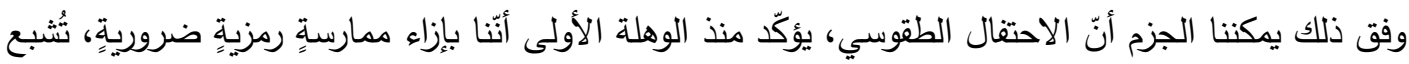

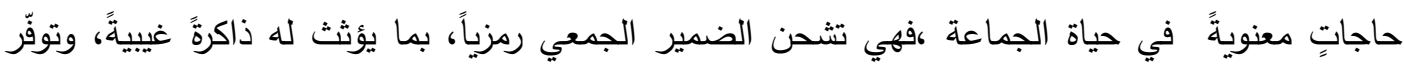

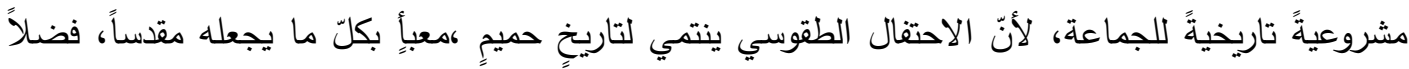

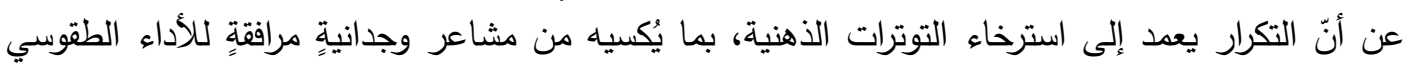

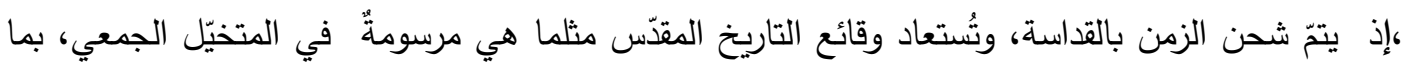

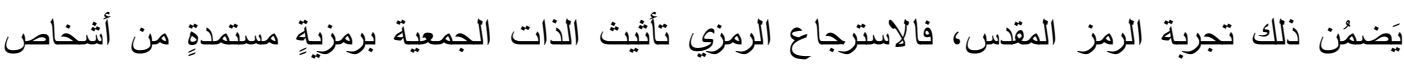

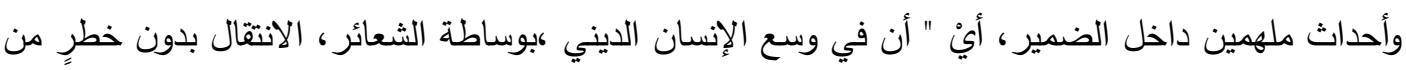

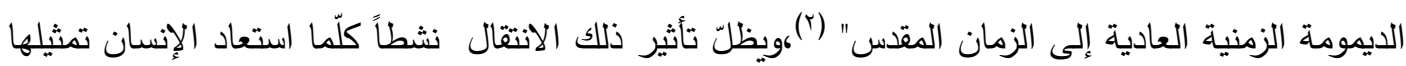

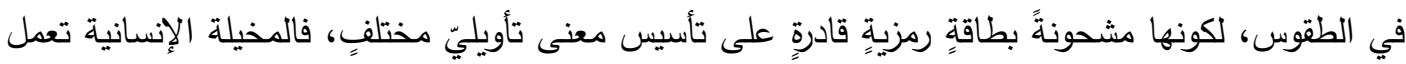

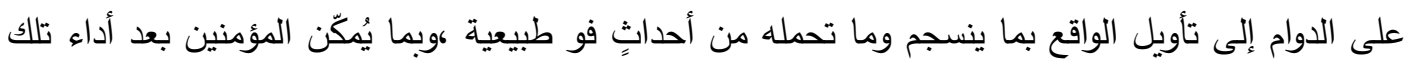

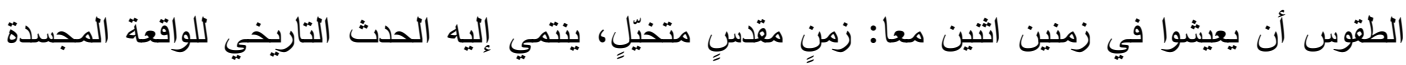

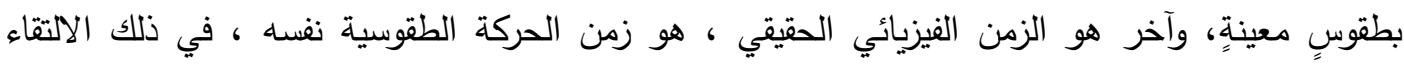


المتصور تتداخل الأزمان، فيصبح القياسي أسطورياً والأسطوريّ جزءً من القياسي، بما يسمح للخيال أنْ

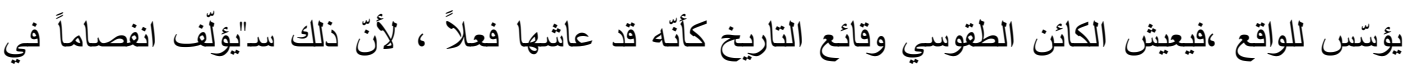

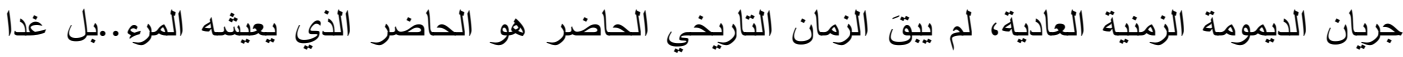
الزمان الذي جرى فيه الوجود التاريخي"('). إذن تؤَّف الطقوس، وما يصاحبها من حركات جسدية ،نوعاً من أنواع الترميم الثقافي لأيَّة مجموعةٍ تعرّضت

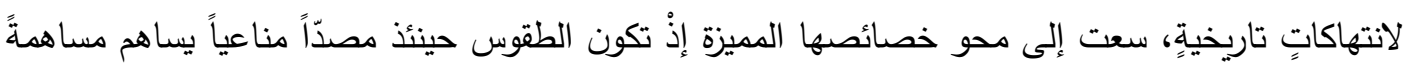

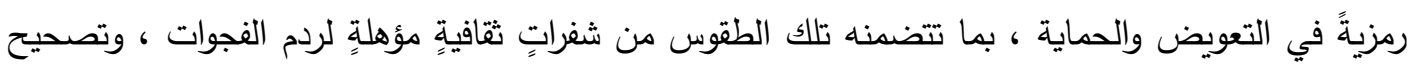

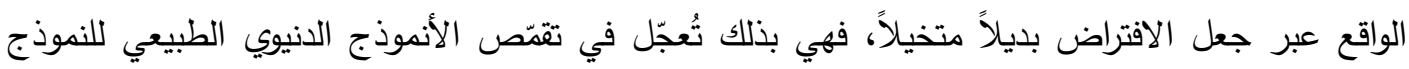

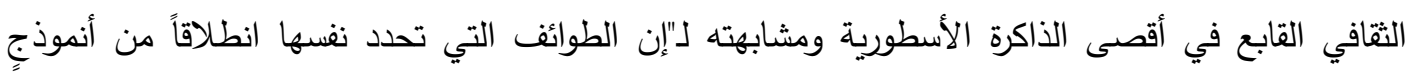

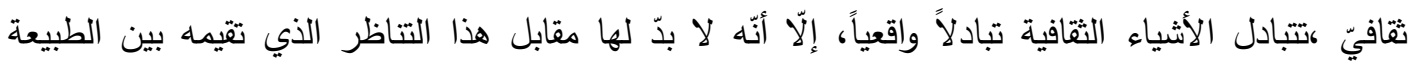

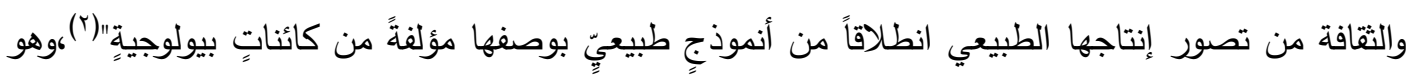

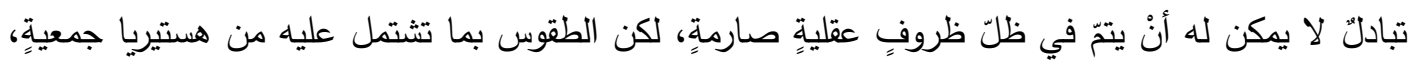

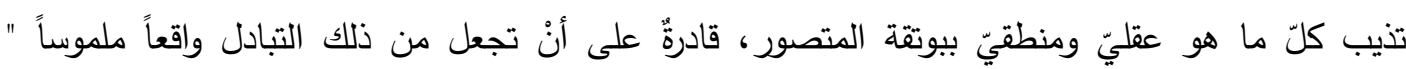

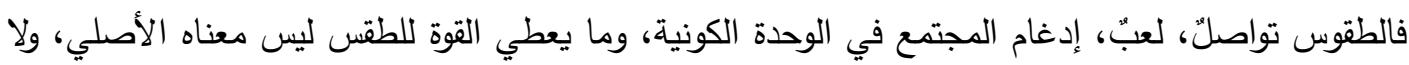

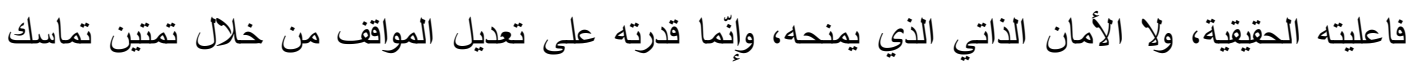

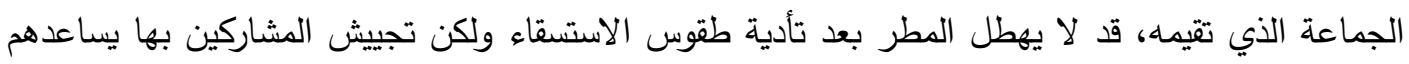

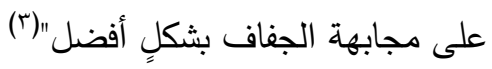
وحيث أنّ الجسد مجال فاعلية الطقوس، لذا كانت حركته أثناء أداء الثعائر تتنمي لذاكرة غيبيةٍة، مع كونها

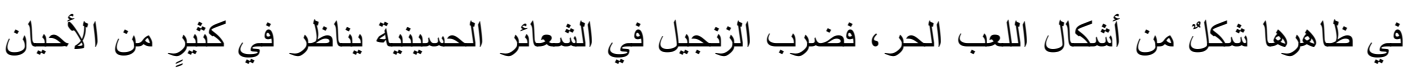

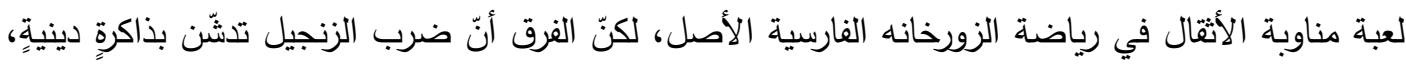

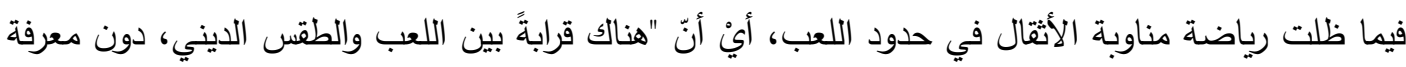

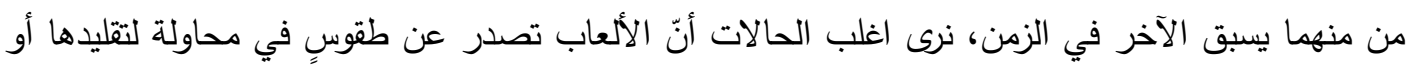

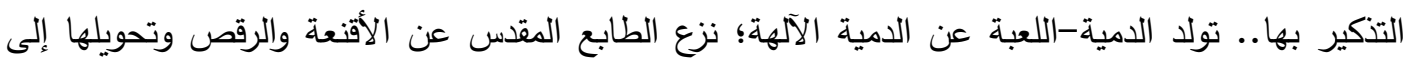

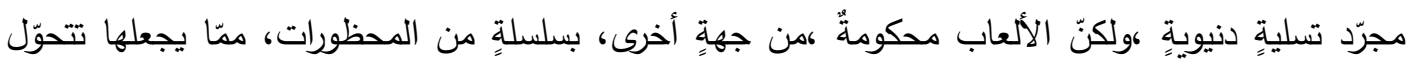

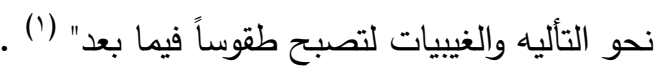

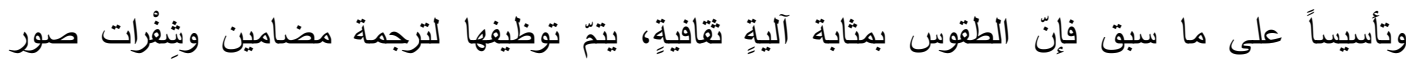

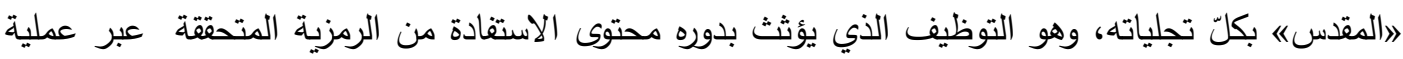


التتشيط الحر للذاكرة الجماعية، ذلك أنّ الشعائر والطقوس بغضّ النظر عن موضوعها تتتمي للذاكرة الثقافية

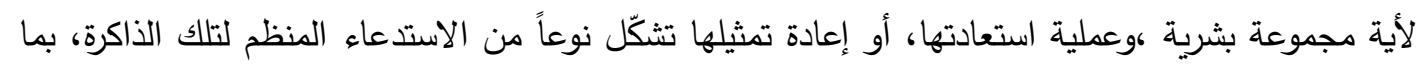
يجعل استقبال الحاضر مُحصّناً بقابليةٍ تاريخيةٍ. 


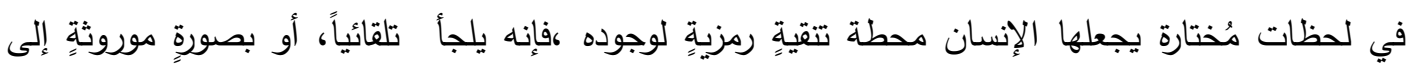

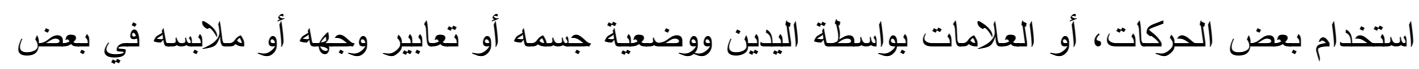

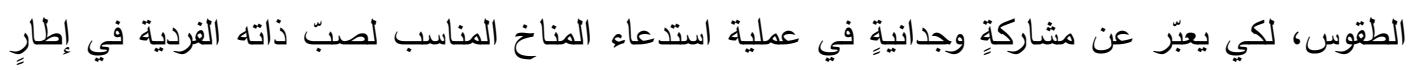

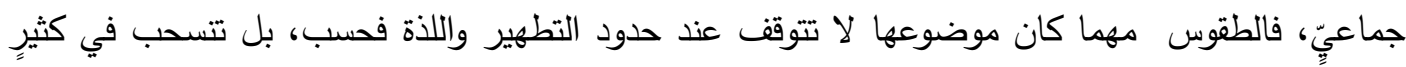

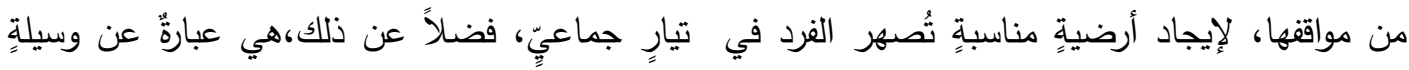

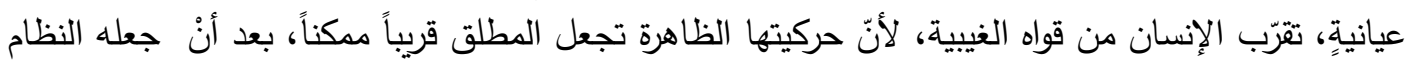

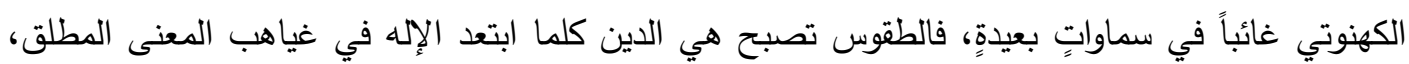

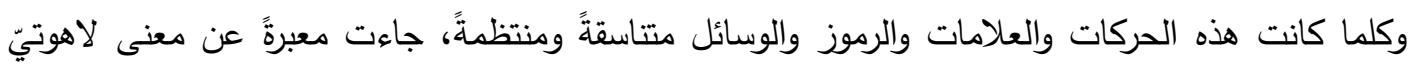

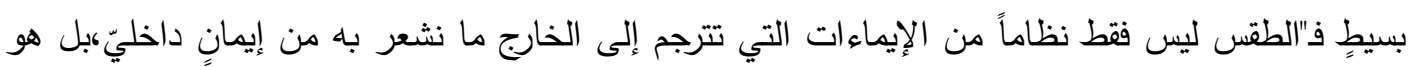

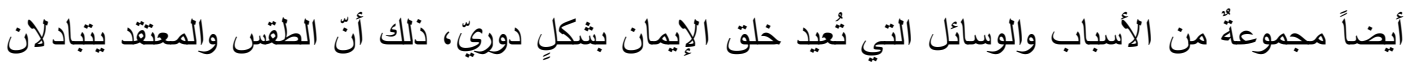

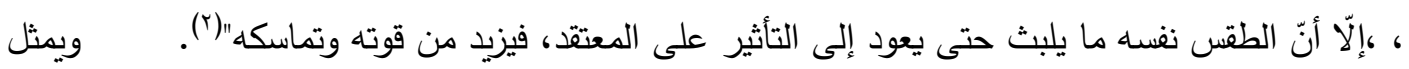

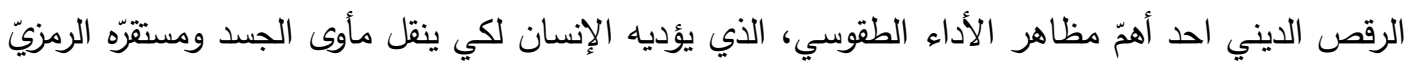

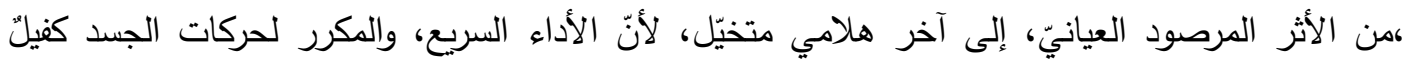

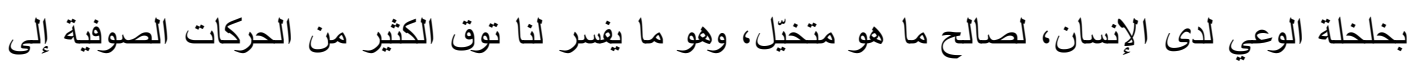

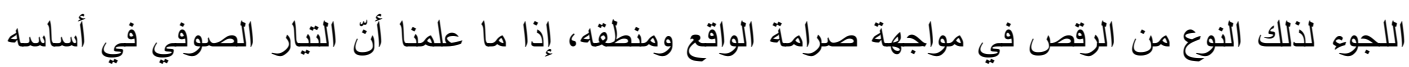

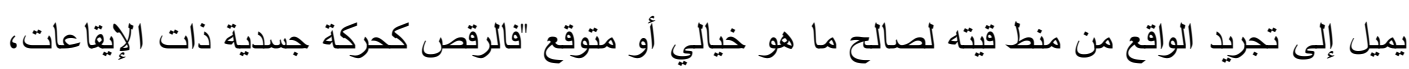

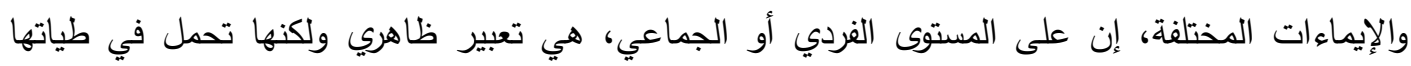

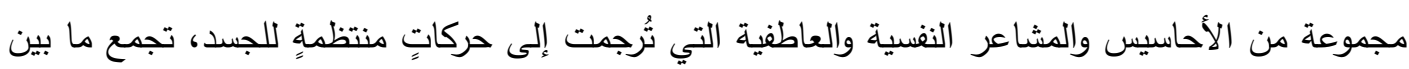

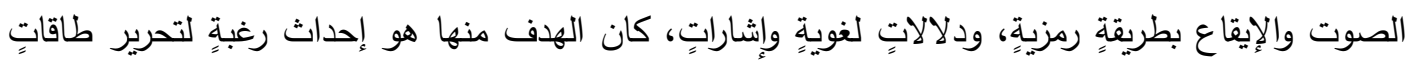

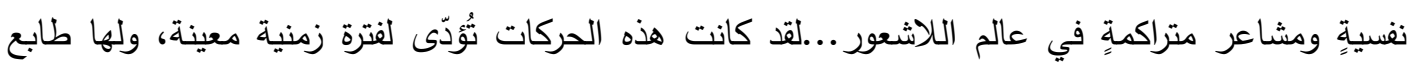
التكرار ، حيث تعود ممارستها لفضاء وزمان معينين، حسب ما تمليه عليها الضغوط الثقافية والاجتماعية

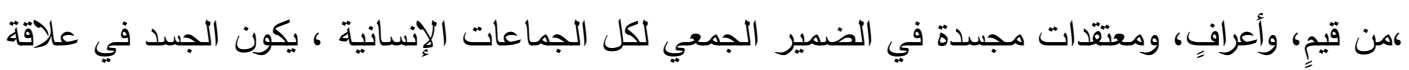

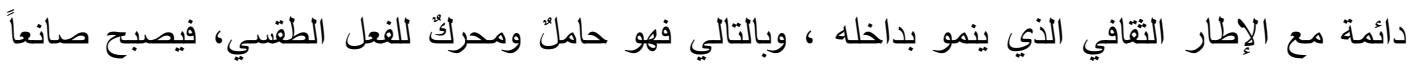
ومنتجاً لتلك الطقوس، فمن خلال علاقة الجسد بالبناء الثقافي والاجتماعي تتطور وتتمو الإمكانيات والحدود

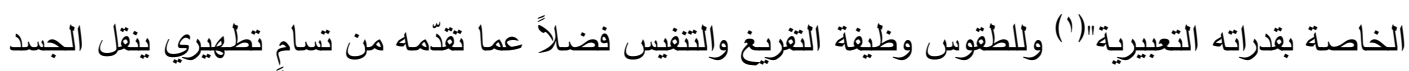
من مصاف الدنيوية إلى مرتبة رمزية متخيلة . 


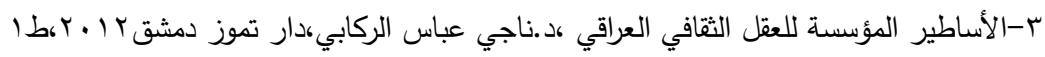

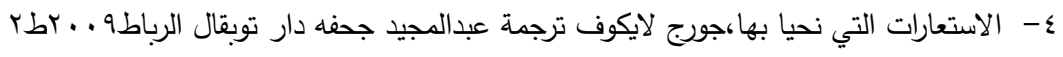

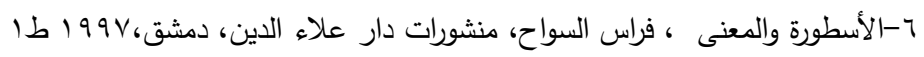

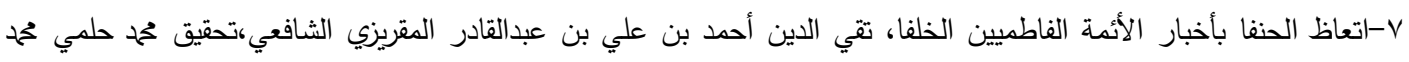

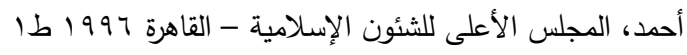

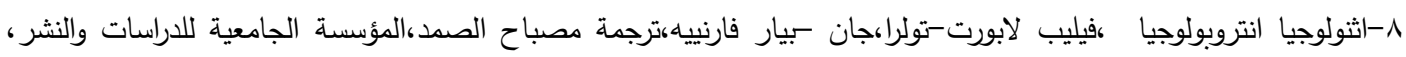

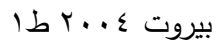

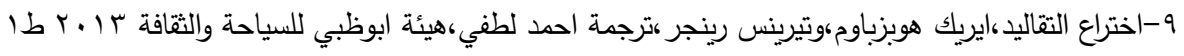

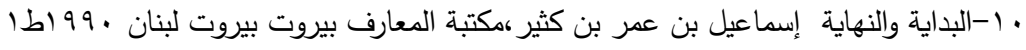

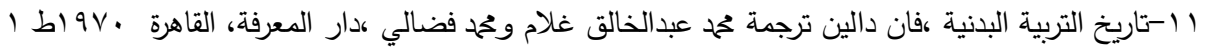

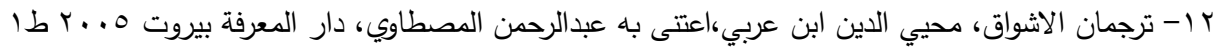

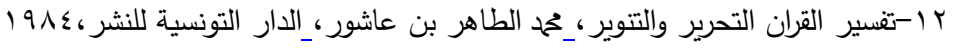

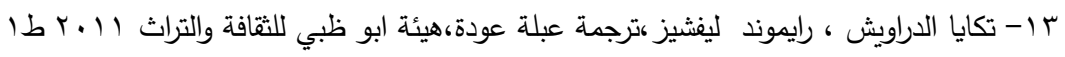

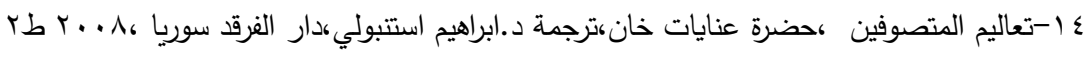

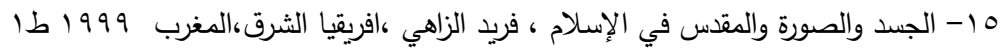

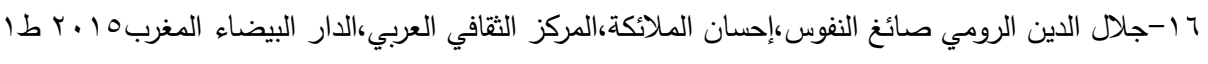

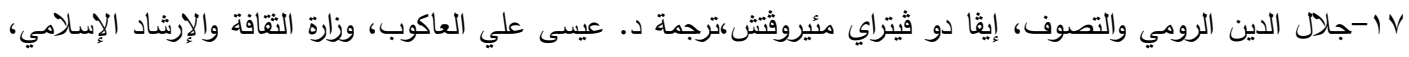

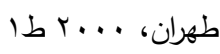

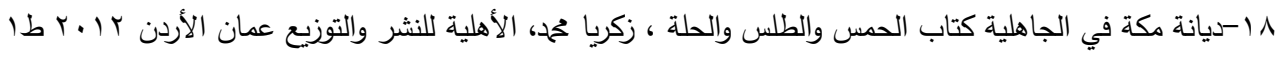

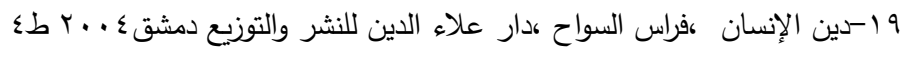

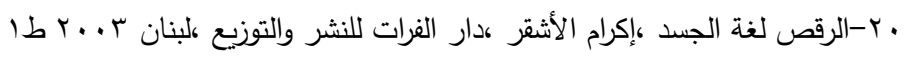

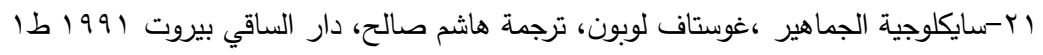

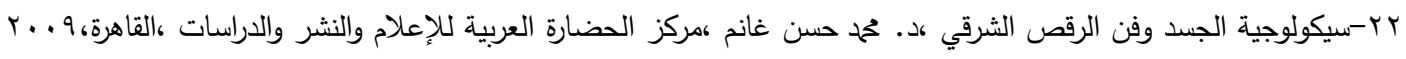

r ب-سوسيولوجيا الدين ،دانيال هيرفيه ليجيه ، جان بول ويلام ،ترجمة درويش الحلوجي ،ا لمجلس الأعلى للثقافة القاهرة O...

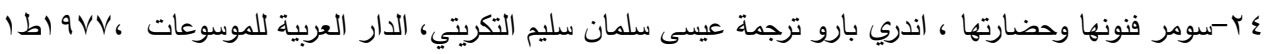

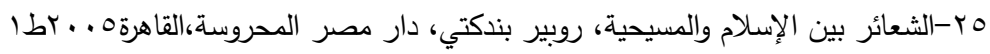

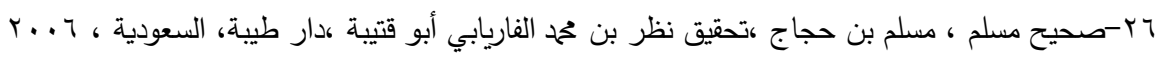


N

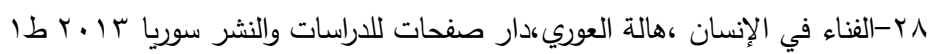

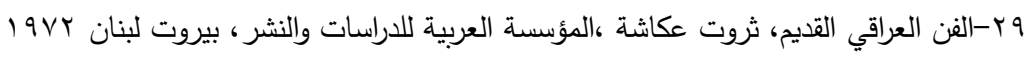

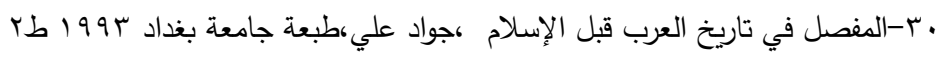

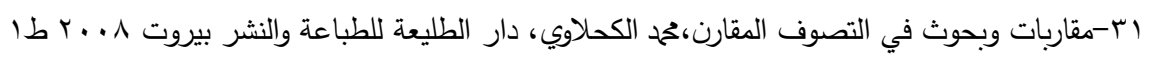

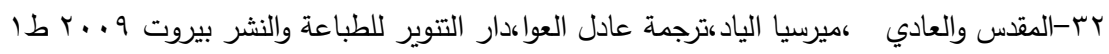

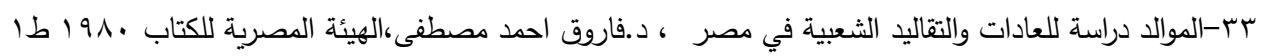

\section{المجلات والصحف}

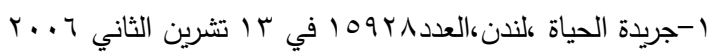

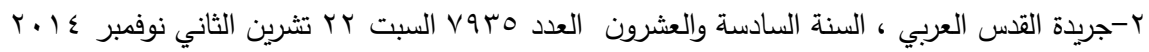

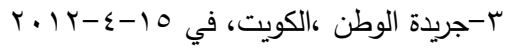

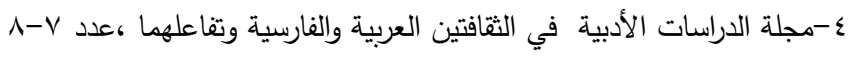

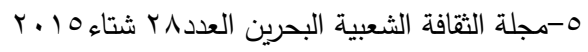

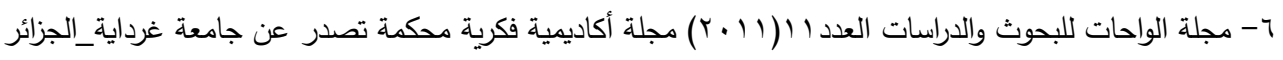

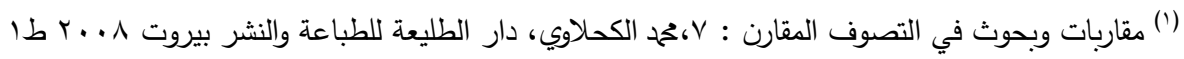

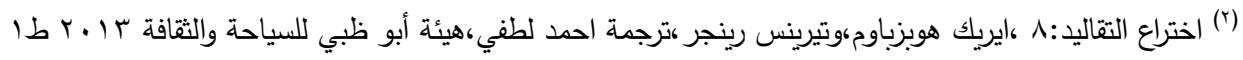

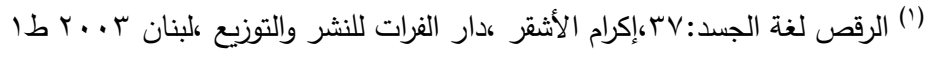

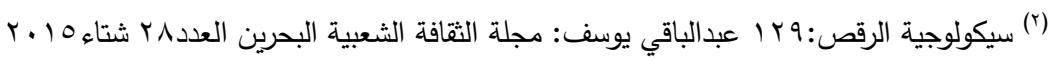

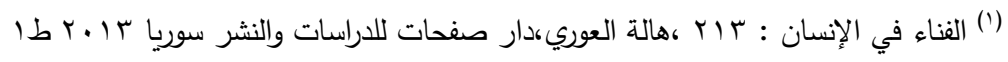

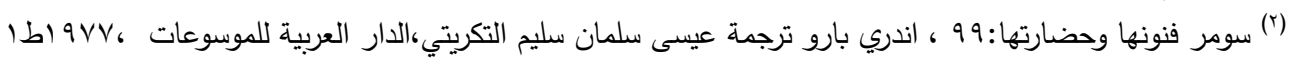

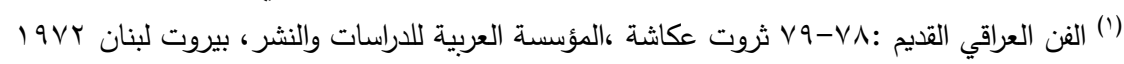

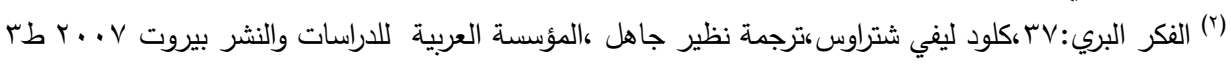

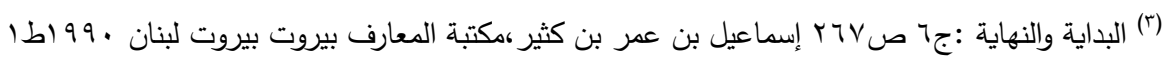

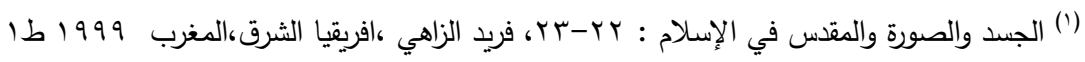

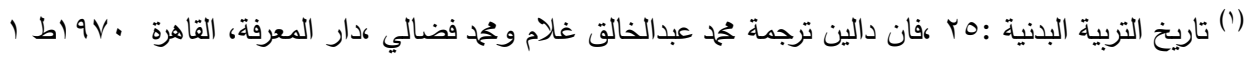

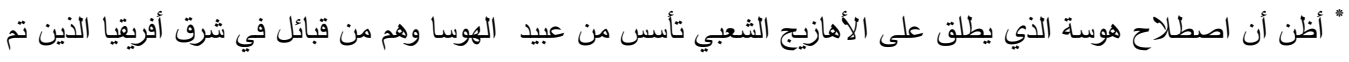
شراؤهم في جنوب العراق واستوطنوا فيه لـاسيما أن اللغة المحكية أطلقت على الثرثرة غير المفهومة اصطلاح هوسة أيضا.

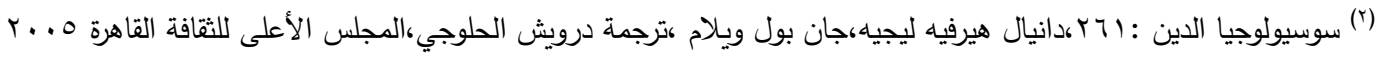


(ץ) الرمزية التجاوزية في مفهوم الرقص عند مولانا جلال الدين الرومي :د ب ا،مجلة الدراسات الأدبية في الثقافتين العربية والفارسية

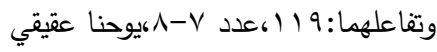

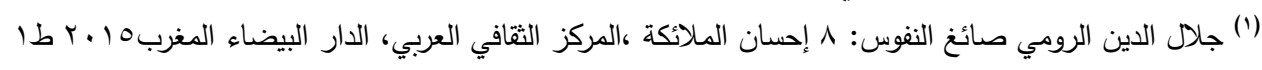

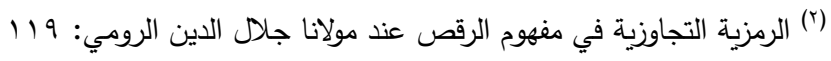

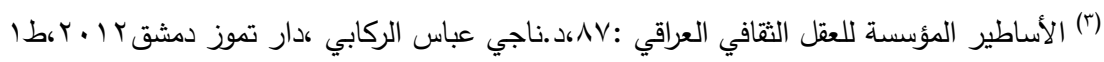

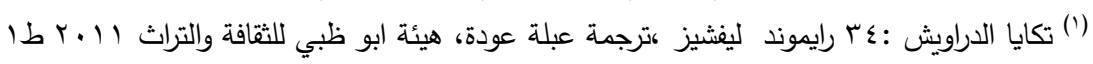

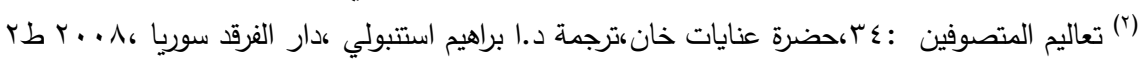

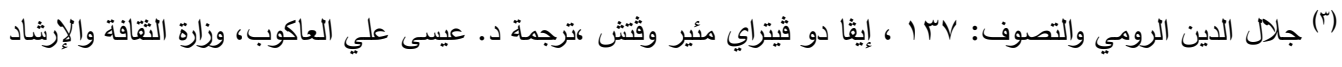

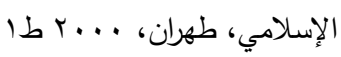

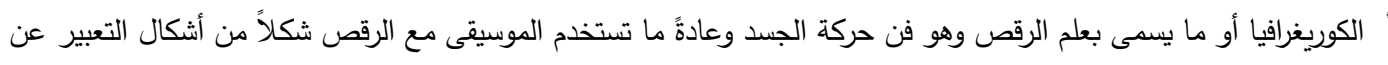

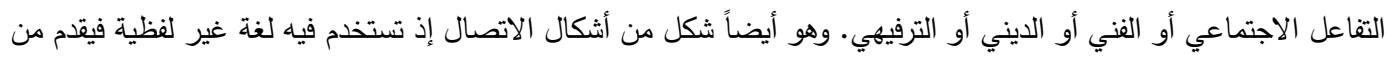

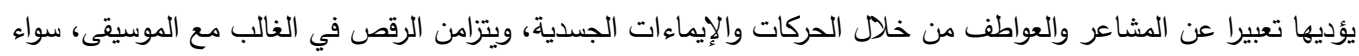

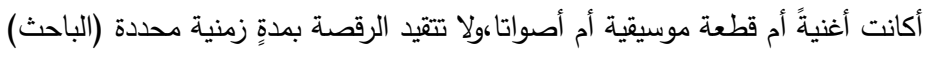

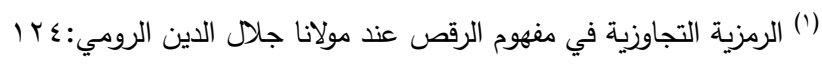

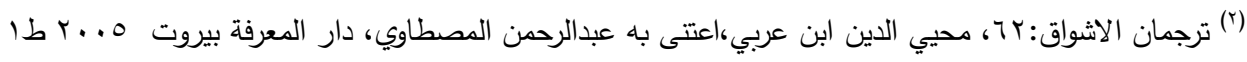

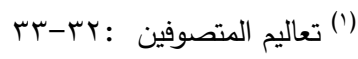

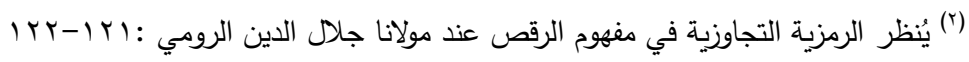

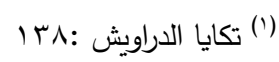

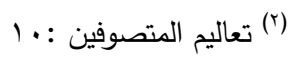
r : : (r)

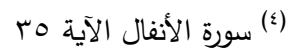

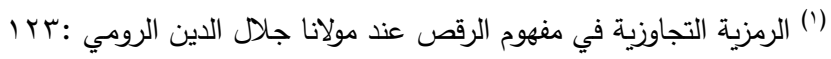

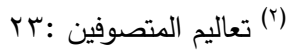
111 : تكايا الدراويش

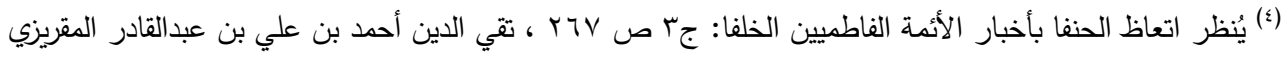

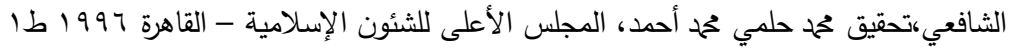

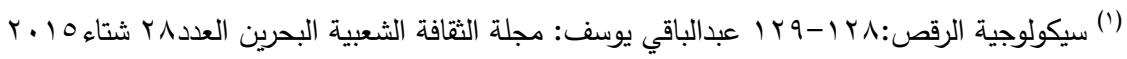
rr)

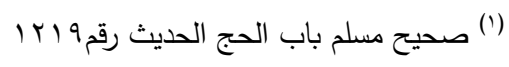

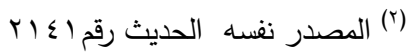

(1) المفصل في تاريخ العرب قبل الإسلام :جף ص 


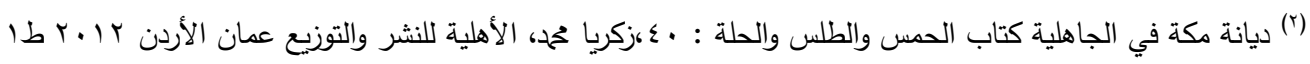

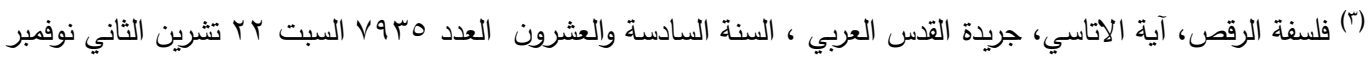

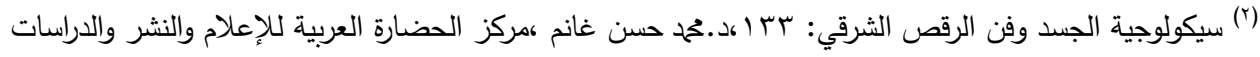

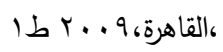

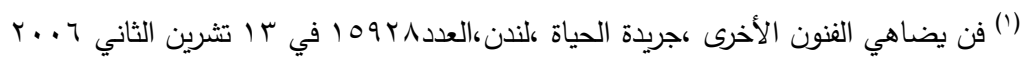

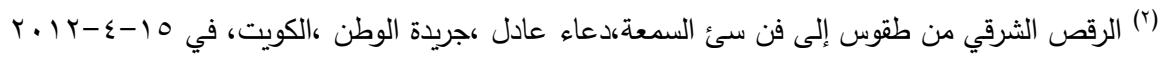

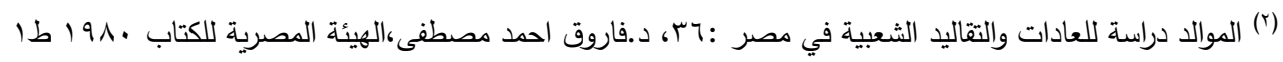

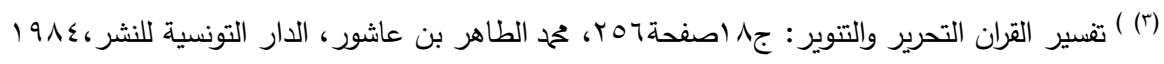

(') الأساطير المؤسسة للعقل الثقافي العراقي: 79

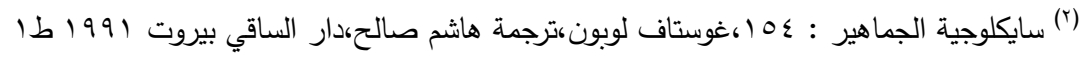

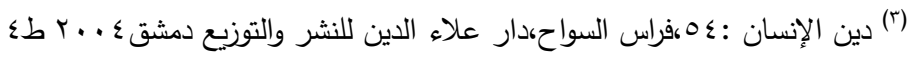

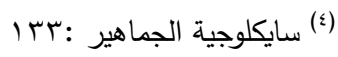

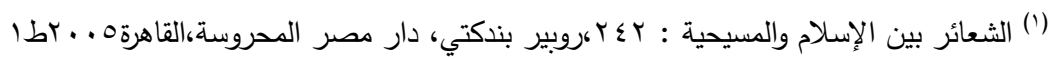

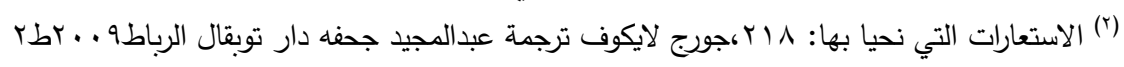

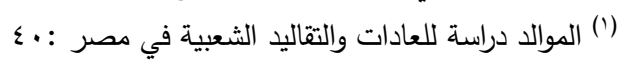

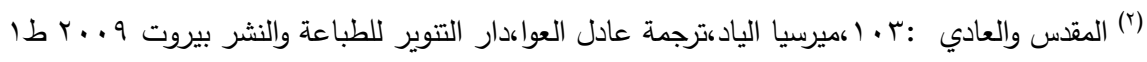

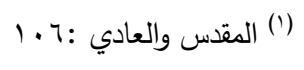

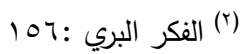

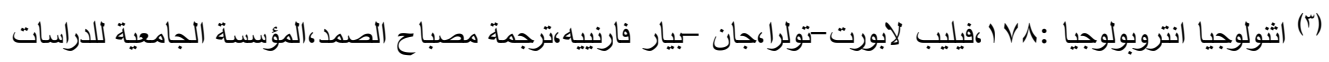

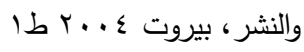

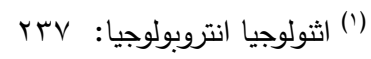

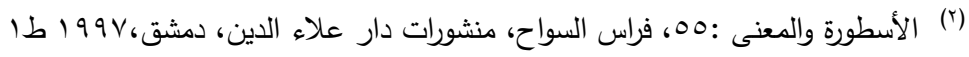

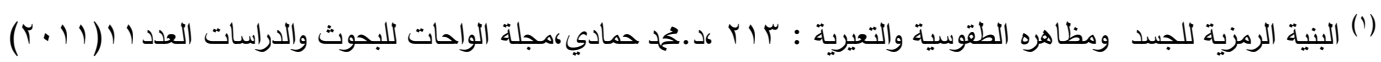
مجلة أكاديمية فكرية محكمة تصدر عن جامعة غرداية_الجزائر 